\title{
Cézeaux-Aulnat-Opme-Puy De Dôme: a multi-site for the long-term survey of the tropospheric composition and climate change
}

\author{
Jean-Luc Baray ${ }^{1,2}$, Laurent Deguillaume ${ }^{1,2}$, Aurélie Colomb ${ }^{1}$, Karine Sellegri ${ }^{1}$, Evelyn Freney ${ }^{1}$, Clémence Rose $^{1}$, \\ Joël Van Baelen ${ }^{1,3}$, Jean-Marc Pichon ${ }^{1,2}$, David Picard ${ }^{1}$, Patrick Fréville ${ }^{2}$, Laëtitia Bouvier ${ }^{1,2}$, Mickaël Ribeiro ${ }^{1}$, \\ Pierre Amato $^{4}$, Sandra Banson ${ }^{1}$, Angelica Bianco ${ }^{1,4}$, Agnès Borbon ${ }^{1}$, Lauréline Bourcier ${ }^{1}$, Yannick Bras ${ }^{1}$, \\ Marcello Brigante ${ }^{4}$, Philippe Cacault ${ }^{2}$, Aurélien Chauvigné ${ }^{1,5}$, Tiffany Charbouillot ${ }^{1,4}$, Nadine Chaumerliac ${ }^{1}$, \\ Anne-Marie Delort ${ }^{4}$, Marc Delmotte ${ }^{6}$, Régis Dupuy ${ }^{1}$, Antoine Farah ${ }^{1}$, Guy Febvre ${ }^{1}$, Andrea Flossmann ${ }^{1}$, \\ Christophe Gourbeyre $^{1}$, Claude Hervier ${ }^{2}$, Maxime Hervo ${ }^{1,7}$, Nathalie Huret ${ }^{1,2}$, Muriel Joly ${ }^{1,4}$, Victor Kazan ${ }^{6}$, \\ Morgan Lopez $^{6}$, Gilles Mailhot ${ }^{2,4}$, Angela Marinoni ${ }^{1,8}$, Olivier Masson ${ }^{9}$, Nadège Montoux ${ }^{1}$, Marius Parazols ${ }^{1,4}$, \\ Frédéric Peyrin $^{2}$, Yves Pointin ${ }^{1}$, Michel Ramonet ${ }^{6}$, Manon Rocco ${ }^{1}$, Martine Sancelme ${ }^{4}$, Stéphane Sauvage ${ }^{10}$, \\ Martina Schmidt $^{6,11}$, Emmanuel Tison ${ }^{10}$, Mickaël Vaïtilingom ${ }^{1,4,12}$, Paolo Villani ${ }^{1}$, Miao Wang ${ }^{1}$, Camille Yver-Kwok ${ }^{6}$, \\ and Paolo Laj 8,13 \\ ${ }^{1}$ Université Clermont Auvergne, CNRS, Laboratoire de Météorologie Physique, UMR 6016, Clermont-Ferrand, France \\ ${ }^{2}$ Université Clermont Auvergne, CNRS, Observatoire de Physique du Globe de Clermont Ferrand, \\ UMS 833, Clermont-Ferrand, France \\ ${ }^{3}$ Université de la Réunion, CNRS, Météo-France, Laboratoire de l'Atmosphère et des Cyclones, \\ UMR 8105, St Denis de la Réunion, France \\ ${ }^{4}$ Université Clermont Auvergne, CNRS, SIGMA Clermont, Institut de Chimie de Clermont-Ferrand, \\ UMR 6296, Clermont-Ferrand, France \\ ${ }^{5}$ Université Lille, CNRS, Laboratoire d'Optique Atmosphérique, UMR 8518, Villeneuve-d'Ascq, France \\ ${ }^{6}$ Université Paris-Saclay CEA-CNRS-UVSQ, Laboratoire des Sciences du Climat et de l'Environnement, \\ UMR 8212, Gif-sur-Yvette, France \\ ${ }^{7}$ Federal Office of Meteorology and Climatology, MeteoSwiss, 1530 Payerne, Switzerland \\ ${ }^{8}$ Institute for Atmospheric Sciences and Climate, National Research Council, Bologna, Italy \\ ${ }^{9}$ Institut de Radioprotection et de Sûreté Nucléaire, Saint-Paul-lez-Durance, France \\ ${ }^{10}$ IMT Lille Douai, Univ. Lille, SAGE - Département Sciences de l'Atmosphère et Génie de l'Environnement, Lille, France \\ ${ }^{11}$ Institut für Umweltphysik, University of Heidelberg, Heidelberg, Germany \\ ${ }^{12}$ Université des Antilles, Laboratoire de Recherche en Géosciences et Energies, EA 4539, Pointe-à-Pitre, Guadeloupe, France \\ ${ }^{13}$ Université Grenoble-Alpes, CNRS, IRD, INPG, IGE UMR 5001, Grenoble, France
}

Correspondence: Jean-Luc Baray (j.1.baray@opgc.fr) and Laurent Deguillaume (laurent.deguillaume@uca.fr)

Received: 8 October 2019 - Discussion started: 4 November 2019

Revised: 7 April 2020 - Accepted: 12 May 2020 - Published: 26 June 2020

Abstract. For the last 25 years, CO-PDD (Cézeaux-Aulnat-
Opme-puy de Dôme) has evolved to become a full instru-
mented platform for atmospheric research. It has received
credentials as a national observing platform in France and
is internationally recognized as a global station in the GAW
(Global Atmosphere Watch) network. It is a reference site
of European and national research infrastructures ACTRIS
(Aerosol Cloud and Trace gases Research Infrastructure) and
ICOS (Integrated Carbon Observing System). The site located on top of the puy de Dôme mountain (1465 ma.s.l.) is completed by additional sites located at lower altitudes and adding the vertical dimension to the atmospheric observations: Opme (660 ma.s.1.), Cézeaux (410 m), and Aulnat $(330 \mathrm{~m})$. The integration of different sites offers a unique combination of in situ and remote sensing measurements capturing and documenting the variability of particulate and

Published by Copernicus Publications on behalf of the European Geosciences Union. 
gaseous atmospheric composition, but also the optical, biochemical, and physical properties of aerosol particles, clouds, and precipitations. Given its location far away from any major emission sources, its altitude, and the mountain orography, the puy de Dôme station is ideally located to sample different air masses in the boundary layer or in the free troposphere depending on time of day and seasons. It is also an ideal place to study cloud properties with frequent presence of clouds at the top in fall and winter. As a result of the natural conditions prevailing at the site and of the very exhaustive instrumental deployment, scientific studies at the puy de Dôme strongly contribute to improving knowledge in atmospheric sciences, including the characterization of trends and variability, the understanding of complex and interconnected processes (microphysical, chemical, biological, chemical and dynamical), and the provision of reference information for climate/chemistry models. In this context, $\mathrm{CO}$ PDD is a pilot site to conduct instrumental development inside its wind tunnel for testing liquid and ice cloud probes in natural conditions, or in situ systems to collect aerosol and cloud. This paper reviews 25 years (1995-2020) of atmospheric observation at the station and related scientific research contributing to atmospheric and climate science.

\section{Introduction}

Atmospheric greenhouse and reactive gases, aerosol particles and atmospheric water (water vapor, clouds and precipitation), as well as their interactions, play a crucial role for weather and climate systems (IPCC, 2013). Despite the vast improvement of global models and satellite observations, the necessity of ground-based long-term observations remains for model assimilation and validation and allows the understanding of atmospheric processes to be improved. It is therefore crucial to maintain fully instrumented stations for the long-term monitoring of the atmospheric composition with a high technological and scientific level. These stations are especially useful within the framework of larger observation networks such as the Global Atmosphere Watch (GAW) program.

CO-PDD combines in situ and remote sensing observations from different connected sites (Cézeaux-Aulnat, Opme, and puy de Dôme) at different altitudes allowing the evolution of the composition of the troposphere of central France to be documented (Fig. 1). The puy de Dôme station (PUY, $45.77^{\circ} \mathrm{N}, 2.96^{\circ} \mathrm{E} ; 1465 \mathrm{ma.s.1}$ ) is located about $15 \mathrm{~km}$ far from immediate pollution sources, Opme $\left(45.71^{\circ} \mathrm{N}, 3.09^{\circ} \mathrm{E}, 660 \mathrm{~m}\right)$ is located in a semi-rural area, and the Cézeaux $\left(45.76^{\circ} \mathrm{N}, 3.11^{\circ} \mathrm{E}, 410 \mathrm{~m}\right)$ and Aulnat sites $\left(45.79^{\circ} \mathrm{N}, 3.15^{\circ} \mathrm{E}, 330 \mathrm{~m}\right)$ are located in a suburban area, near the city of Clermont-Ferrand. The sites are 10 to $15 \mathrm{~km}$ apart.
PUY is the highest point of the Chaîne des Puys, a northsouth-oriented volcanic mountain range, presenting an orographic barrier to the prevailing oceanic westerly winds, documented by trajectory analysis (Hervo et al., 2014). The height of the mixing layer varies between day and night and as a function of the meteorological conditions between $700 \mathrm{~m}$ and $2200 \mathrm{~m}$ a.s.1. (Farah et al., 2018). The altitude puts PUY below or above the atmospheric mixing layer, depending on season. PUY is in free tropospheric conditions $50 \%$ of the time in winter, but it is in the mixing layer most of the time in summer. In addition, dynamical exchanges between these two atmospheric compartments can occur and significantly influence the lifetime and transport of aerosol particles injected into the free troposphere (Freney, 2016). A systematic analysis of webcam images shows that the PUY summit is in cloudy conditions on average $30 \%$ of the time; the cloud occurrence varies from $24 \%$ in summer to $60 \%$ in winter (Baray et al., 2019). The variety of cloud situations encountered (orographic, frontal, convective clouds) makes the PUY station a strategic location for cloud observations.

The station serves the objective of providing to the scientific community a facility for hosting experiments and a set of long-term measurements to investigate the processes linking gases, aerosols, clouds, and precipitation and the impact of anthropogenic changes on climate (cloud, radiation) and meteorology (precipitation). It is a unique place to study key research topics such as the nucleation of new particles and their interactions with atmospheric water vapor, bio-physicochemistry of clouds, or secondary organic aerosol formation resulting from gas-phase precursors.

CO-PDD has been in operation for more than 25 years. The purpose of this paper is to provide an overview of this station, including its history (Sect. 2), the scientific context and main scientific questions (Sect. 3), the national and international structuration (Sect. 4), a technical description of the observation systems (Sect. 5), some highlights of major scientific results derived from CO-PDD observations (Sect. 6), and future plans and concluding remarks (Sect. 7). The list of acronyms and the encountered air masses are given in Appendices $\mathrm{A}$ and $\mathrm{B}$.

\section{History}

The puy de Dôme mountain has a very long history of contributing to atmospheric sciences. Already in September 1648, Blaise Pascal and his brother-in-law Florin Périer performed the Torricelli experiment at the puy de Dôme to prove the change in the atmospheric pressure with altitude. Two centuries later, the destruction of the French fleet during the Crimean War by a storm in 1854 was the triggering event for the study of meteorology in France. The history of the observatory at the top of the puy de Dôme begins in 1869, when Émile Alluard (1815-1908), professor of physics at the Faculty of Sciences of Clermont-Ferrand, 
Table 1. List of instruments deployed at PUY.

\begin{tabular}{|c|c|c|c|c|c|}
\hline Instrument & Parameter & $\begin{array}{l}\text { Measurement } \\
\text { period }\end{array}$ & $\begin{array}{l}\text { Typical } \\
\text { temporal } \\
\text { resolution }\end{array}$ & $\begin{array}{l}\text { Network, research } \\
\text { infrastructure, national } \\
\text { and local services }\end{array}$ & $\begin{array}{l}\text { Laboratory involved } \\
\text { (other than LaMP } \\
\text { or OPGC) }\end{array}$ \\
\hline Sonic anemometer & Wind speed and direction & 1995-present & $5 \min$ & & \\
\hline Meteorological station & $\begin{array}{l}\text { Pressure, temperature, } \\
\text { humidity }\end{array}$ & 1995-present & $5 \mathrm{~min}$ & & \\
\hline ACSM (Aerodyne) & $\begin{array}{l}\text { Aerosol chemical } \\
\text { composition }\end{array}$ & 2015-present & $10 \mathrm{~min}$ & CLAP, ACTRIS, GAW & \\
\hline MAAP & Black carbon & 2000-present & $5 \mathrm{~min}$ & CLAP, ACTRIS, GAW & \\
\hline CPC (TSI) & Total aerosol number & 2000-present & $5 \mathrm{~min}$ & CLAP, ACTRIS, GAW & \\
\hline SMPS, OPC Grimm & Aerosol size distribution & 2001-present & $5 \min$ & CLAP, ACTRIS, GAW & \\
\hline Photometer & Aerosol optical depth & 2005-present & $1 \mathrm{~h}$ & CLAP, ACTRIS, GAW & \\
\hline TEOM & Aerosol mass & 2005-present & $2 \min$ & CLAP, ACTRIS, GAW & \\
\hline (N)AIS & $\begin{array}{l}\text { Aerosol (charged and/ } \\
\text { or neutral) size distribution }\end{array}$ & 2006-2015 & $5 \mathrm{~min}$ & CLAP, ACTRIS, GAW & \\
\hline PSM & $\begin{array}{l}\text { Cluster particles size } \\
\text { distribution }\end{array}$ & 2011-2014 & $1-4 \min$ & & \\
\hline HTDMA (homemade) & Aerosol hygroscopicity & 2008-2012 & $3 \mathrm{~h}$ & ACTRIS & \\
\hline Scanotron (homemade) & $\mathrm{CCN}$ & 2012-present & $10 \mathrm{~min}$ & ACTRIS & \\
\hline Nephelometer (TSI) & Scattering coefficient & 2003-present & $5 \mathrm{~min}$ & CLAP, ACTRIS, GAW & \\
\hline Filter & Radionuclide aerosols & 2005-present & 1 week & OPERA & IRSN \\
\hline Alpha spectrometer & Radon-222 & 2002-present & $2 \mathrm{~h}$ & RAMCES & LSCE, Paris \\
\hline $\begin{array}{l}\text { Fluorescence UV } \\
\text { (TEI } 43 \text { CTL) }\end{array}$ & $\mathrm{SO}_{2}$ & 1995-present & $5 \mathrm{~min}$ & PUY-GAZ, EMEP & \\
\hline $\begin{array}{l}\text { UV absorption } \\
\text { (TEI } 49 \text { i) }\end{array}$ & $\mathrm{O}_{3}$ & 1995-present & $5 \mathrm{~min}$ & PUY-GAZ, EMEP, GAW & \\
\hline $\begin{array}{l}\text { Infra-Red absorption } \\
\text { (TEI) }\end{array}$ & $\mathrm{CO}$ & 2002-2012 & $5 \mathrm{~min}$ & PUY-GAZ, EMEP, ICOS & \\
\hline $\begin{array}{l}\mathrm{O}_{3} \text { chemiluminescence } \\
\text { (TEI } 42 \mathrm{CTL} \text { ) }\end{array}$ & $\mathrm{NO}_{x}$ & 2003-present & $5 \mathrm{~min}$ & $\begin{array}{l}\text { PUY-GAZ, EMEP, } \\
\text { ACTRIS, GAW }\end{array}$ & \\
\hline $\begin{array}{l}\text { GC-MS } \\
\text { (Perkin Elmer) }\end{array}$ & $\begin{array}{l}\text { VOC (NMHCs, } \\
\text { BVOC) }\end{array}$ & $\begin{array}{l}\text { 2010-2016 } \\
\text { 2017-present }\end{array}$ & $\begin{array}{l}\text { On campaign } \\
\text { Once a week }\end{array}$ & $\begin{array}{l}\text { PUY-GAZ, ACTRIS, } \\
\text { GAW }\end{array}$ & \\
\hline NDIR (Licor) & $\mathrm{CO}_{2}$ & 2000-2012 & $5 \mathrm{~min}$ & RAMCES & LSCE, Paris \\
\hline CRDS (Picarro) & $\mathrm{CO}_{2}, \mathrm{CH}_{4}, \mathrm{CO}$ & $2012-2015$ & $5 \mathrm{~min}$ & RAMCES, ICOS & LSCE, Paris \\
\hline GC-FID/ECD (Agilent) & $\mathrm{CO}_{2}, \mathrm{CH}_{4}, \mathrm{~N}_{2} \mathrm{O}, \mathrm{SF}_{6}$ & 2010-2015 & $5 \mathrm{~min}$ & RAMCES, ICOS & LSCE, Paris \\
\hline GC-FID (Agilent) & NMHCs & 2018-present & $2 \mathrm{~h}$ & $\begin{array}{l}\text { PUY-GAZ, } \\
\text { ACTRIS, GAW }\end{array}$ & \\
\hline $\begin{array}{l}\text { Cloud impactor } \\
\text { (homemade) }\end{array}$ & $\begin{array}{l}\text { Chemical and biological } \\
\text { composition }\end{array}$ & 2003-present & $2 \mathrm{~h}$ & PUY-CLOUD & ICCF \\
\hline $\begin{array}{l}\text { Hi-volume impingers } \\
\text { (Kärcher DS6) }\end{array}$ & $\begin{array}{l}\text { Microorganisms and } \\
\text { biological particles in } \\
\text { clouds and aerosols }\end{array}$ & 2014-present & $2 \mathrm{~h}$ & PUY-CLOUD & ICCF \\
\hline Impactor & Radionuclide cloud & 2007-present & 1 week & OPERA & IRSN \\
\hline GPS & Integrated water vapor & 2011-present & $1 \mathrm{~h}$ & RENAG & \\
\hline
\end{tabular}




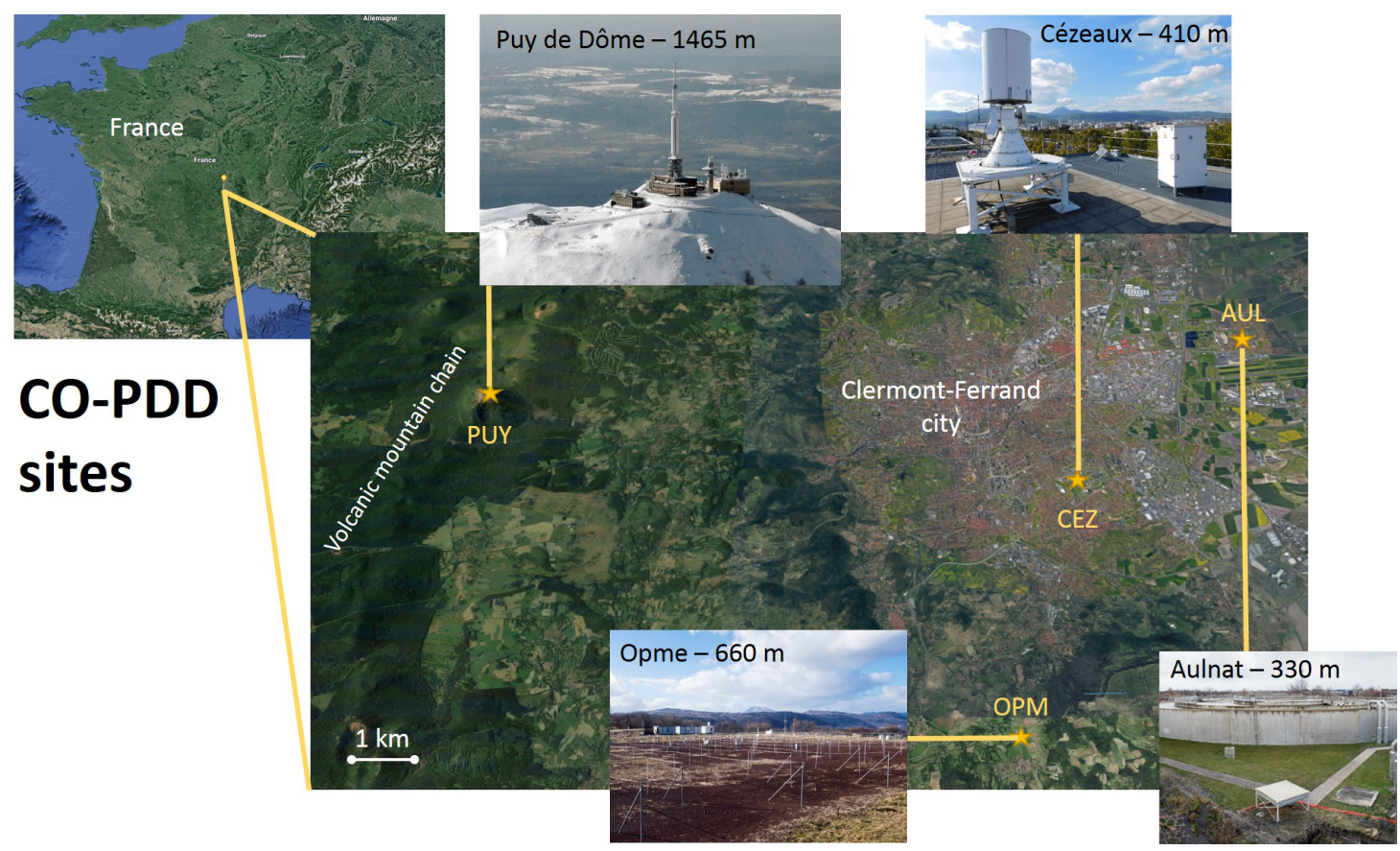

Figure 1. Overview maps showing the location and photos of the CO-PDD sites. This figure was created using $\odot$ Google Maps.

Table 2. List of instruments deployed at Opme.

\begin{tabular}{|c|c|c|c|c|c|}
\hline Instrument & Parameter & $\begin{array}{l}\text { Measurement } \\
\text { period }\end{array}$ & $\begin{array}{l}\text { Typical } \\
\text { temporal } \\
\text { resolution }\end{array}$ & $\begin{array}{l}\text { Network, research } \\
\text { infrastructure, } \\
\text { national and } \\
\text { local services }\end{array}$ & $\begin{array}{l}\text { Laboratory } \\
\text { involved } \\
\text { (other than } \\
\text { LaMP or } \\
\text { OPGC) }\end{array}$ \\
\hline Meteorological station & $\begin{array}{l}\text { Pressure, temperature, } \\
\text { humidity }\end{array}$ & 2017-present & $5 \mathrm{~min}$ & & \\
\hline Rain gauge & Precipitation & 1998-present & $5 \mathrm{~min}$ & & \\
\hline Disdrometer & Precipitations & 2006-present & $5 \mathrm{~min}$ & & \\
\hline \multirow{3}{*}{ VHF profiler } & Wind profiles & $1998-2015$ & $15 \mathrm{~min}$ & E-Profile & \\
\hline & Radionuclide aerosols & 2004-present & 1 week & OPERA & IRSN \\
\hline & Radionuclide rain & 2004-present & 1 month & OPERA & IRSN \\
\hline MRR & Rain reflectivity profiles & 2006-present & $5 \mathrm{~min}$ & & \\
\hline Precipitation collector & $\begin{array}{l}\text { Biological ice nucleating } \\
\text { particles, chemical composition }\end{array}$ & 2015-present & $1 \mathrm{~d}$ & & $\mathrm{ICCF}$ \\
\hline GPS & Integrated water vapor & 2011-present & $1 \mathrm{~h}$ & RENAG & \\
\hline
\end{tabular}

suggested to the political authorities to install a mountain meteorological observatory at the top of the puy de Dôme. The construction began in 1872 , was completed in 1875 , and was inaugurated on 22 August 1876. The observatory was composed of two stations: the upper station at the top of the puy de Dôme summit and a lowland station located about $1000 \mathrm{~m}$ below, in the city of Clermont-Ferrand (Fig. 2). The upper station was a $7 \mathrm{~m}$ tower, connected to the house of the station keeper by a tunnel and equipped with thermometers, anemometers, a mercury-recording barometer, a Hasler thermo-hygrograph, a rain gauge, and a condensation hygrometer (Anon, 1876). The responsibility of the observatory changed in 1925, becoming the Institut et Observatoire de Physique du Globe (IOPG) of Clermont-Ferrand; 45 years later, a research laboratory, the Laboratoire de Dynamique et Microphysique de l'Atmosphère (LDMA), was 
Table 3. List of instruments deployed at Cézeaux and Aulnat.

\begin{tabular}{|c|c|c|c|c|c|}
\hline Instrument & Parameter & $\begin{array}{l}\text { Measurement } \\
\text { period }\end{array}$ & $\begin{array}{l}\text { Typical } \\
\text { temporal } \\
\text { resolution }\end{array}$ & $\begin{array}{l}\text { Network, research } \\
\text { infrastructure, } \\
\text { national and } \\
\text { local services }\end{array}$ & $\begin{array}{l}\text { Laboratory } \\
\text { involved } \\
\text { (other than } \\
\text { LaMP or } \\
\text { OPGC) }\end{array}$ \\
\hline Meteorological station & Pressure, temperature, humidity & 2002-present & $5 \min$ & & \\
\hline Rain gauge & Precipitations & 1994-present & $5 \min$ & & \\
\hline MRR & Rain reflectivity profiles & 2014-present & $5 \mathrm{~min}$ & & \\
\hline Band $\mathrm{X}$ radar & Rain reflectivity & 2006-present & $15 \min$ & & \\
\hline GPS & Integrated Water Vapor & 2007-present & $1 \mathrm{~h}$ & RENAG & $\begin{array}{l}\text { ENSTA } \\
\text { Bretagne }\end{array}$ \\
\hline Disdrometer & Precipitations & 2007-present & $5 \min$ & & \\
\hline LIDAR & $\begin{array}{l}\text { Aerosol/ } / \mathrm{H}_{2} \mathrm{O} \text { profiles, } \\
\text { cirrus }\end{array}$ & 2008-present & $\begin{array}{l}\text { From } 1 \mathrm{~min} \\
\text { to } 1 \mathrm{~d}\end{array}$ & $\begin{array}{l}\text { EARLINET, } \\
\text { ACTRIS }\end{array}$ & \\
\hline UHF profiler & Wind profiles & 2014-present & $15 \min$ & E-Profile & LA Toulouse \\
\hline Full sky imager & Cloud fraction & 2015-present & $10 \mathrm{~min}$ & & \\
\hline
\end{tabular}

created at the University of Clermont-Ferrand by Professor Guy Soulage in 1970, becoming the current Laboratoire de Météorologie Physique (LaMP) in 1977 when associated with the French National Centre for Scientific Research (CNRS). In 1986, the observatory merged with the Atmospheric Research Group and the Department of Earth Sciences to form the Observatory of the Sciences of the Universe (OSU) named the Observatoire de Physique du Globe de Clermont-Ferrand (OPGC). In this framework, starting in the late 80 s, the LaMP/OPGC began to perform precipitation measurements with mobile instruments deployed in the basin of Clermont (Cézeaux and Opme) and dynamical measurements with wind profilers. Measurement campaigns have also been performed on other sites such as the "Cévénol" region (ANATOL radar in the S Band, rain gauges and, since 2006, disdrometers, micro rain, and X-band radars). Cézeaux has also hosted a lidar system in operation since 2008. Two intermediate sites were also instrumented for a better description of the dynamical and meteorological context: Opme in 1999 and more recently Aulnat in 2012. The microphysical and chemical observations at the puy de Dôme began in 1995. The puy de Dôme chalet was completely renovated in 2010. More than 70 atmospheric variables are currently measured at PUY, Cézeaux, Aulnat, and Opme (Fig. 3). The exhaustive list of measurement systems currently in operation at PUY, Opme, and Cézeaux/Aulnat is given in Tables 1, 2, and 3, respectively. Figure 4 presents a time series of temperature measured at PUY, compiling historical and current data sets. For hourly averages, the coldest temperature measured at PUY is $-27.2^{\circ} \mathrm{C}$, on 10 February 1956 , and the hottest temperature is $+30.1{ }^{\circ} \mathrm{C}$, on 27 June 2019 . This temperature record was measured when a short heat wave occurred over western Europe, caused by a mass of hot air coming from the Sahara. Average temperatures exceeded by $2{ }^{\circ} \mathrm{C}$ the regular mean. It became the hottest June ever recorded in Europe (COPERNICUS, 2020a). The linear regression line on all points has a slope of $+1.4 \pm 0.7^{\circ} \mathrm{C}$ per century (Fig. 4). This increase is not far from the increase of almost $2{ }^{\circ} \mathrm{C}$ of the European air temperature series since the latter half of the 19th century, recorded from different data sets of ECMWF; KNMI; NASA; Met Office Hadley Centre, NOAA; and JMA (COPERNICUS, 2020b).

\section{Scientific questions}

One objective of CO-PDD is to document the evolution of the tropospheric composition over long periods, to quantify the role of anthropogenic emissions in this evolution, and to contribute to better understanding of atmospheric processes driving the observed variability. The localization of the stations and the complementarity of remote sensing and in situ measurements are optimal to evaluate local/regional transport and environmental variability of atmospheric components. The stations are equipped with various sensors and analyzers to document chemical, biophysical, and physical properties of gases, aerosols, clouds, and precipitation. The wind tunnel at PUY allows more particularly the study of cloud microphysical properties under natural atmospheric conditions (see Sect. 5 for a technical description). These complex atmospheric processes, especially gas-aerosol-cloud interactions, are still poorly understood and parameterized in models (from the detailed process models to the more parame- 

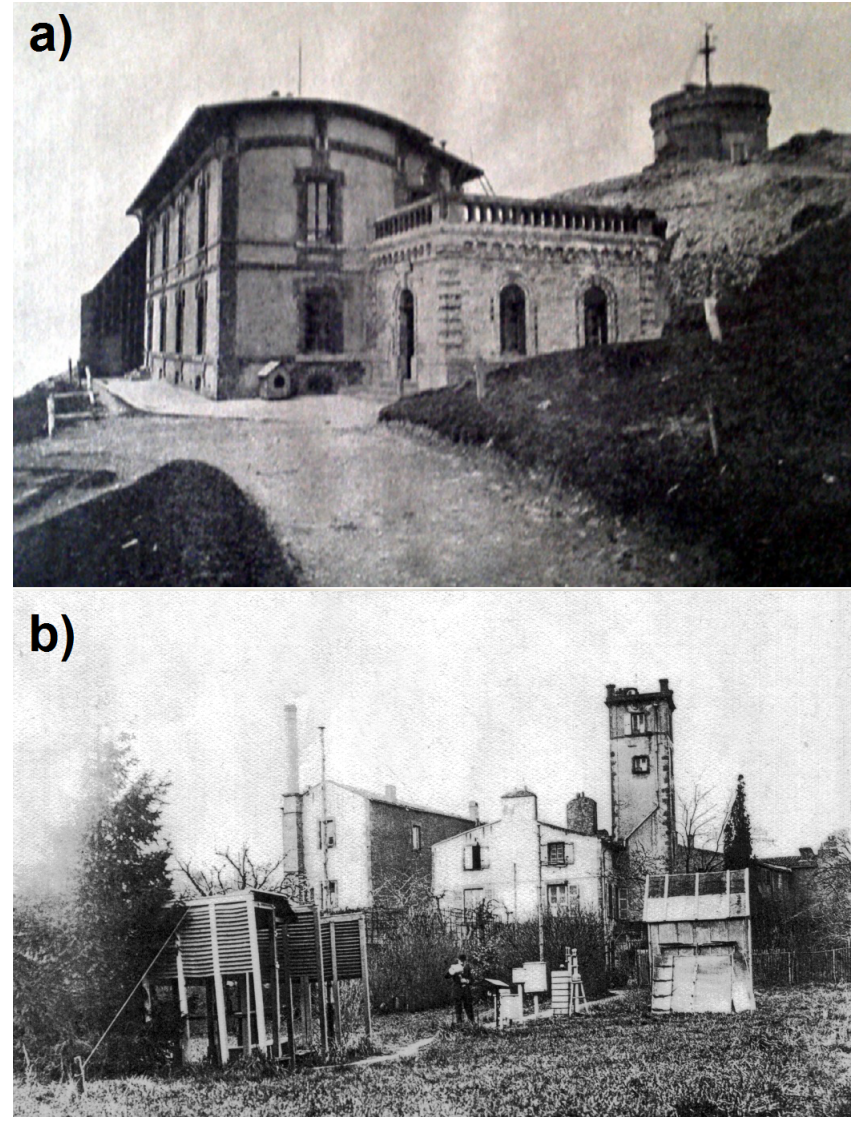

Figure 2. Historical views of the observatory. (a) Living chaletstyle house in front of the observation tower at the top of the puy de Dôme volcano; (b) lowland station in the center of ClermontFerrand, rue Rabanesse.

terized chemistry/transport and global models). Those processes have to be studied considering atmospheric transport that is investigated by remote sensing and modeling. More specifically, a panel of key scientific topics exists for all the investigations performed within the CO-PDD activities and that will be continued or developed in the future (Fig. 5).

- Long-term evolution of the multiphase chemical composition at CO-PDD allows us to analyze the anthropogenic influence and to characterize/discriminate the temporal evolution of sources (gas/aerosol). In this framework, the location of the PUY station near the interface between the mixing layer and the free troposphere allows us to study these time evolutions in different and contrasted situations.

- The configuration of the CO-PDD observation site allows the description of complex interactions between atmospheric components (gas, aerosol particle, water) under natural conditions. Aerosol nucleation processes, gas to liquid partitioning, and cloud condensation nuclei $(\mathrm{CCN}) /$ ice nuclei (IN) properties of aerosol parti-

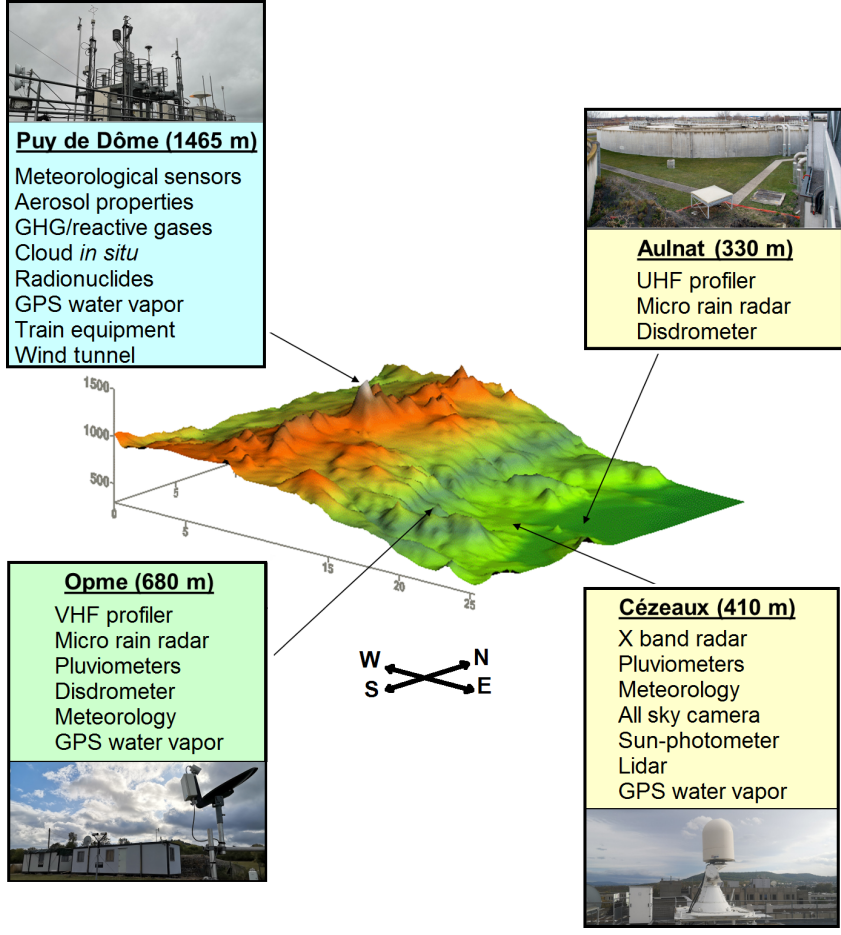

Figure 3. Instruments and measurement sites of the CO-PDD atmospheric research station.

cles have been for example extensively studied, resulting in instrumental developments.

- The transformation processes of gas-phase precursors to secondary aerosol (SOA) are also actively studied. They can be of a chemical (oxidation processes of the organic matter), physical (microphysical processes linking water vapor, liquid and ice clouds, and precipitation), or biological (role of microorganisms in consuming/producing new chemical compounds in the cloud water) nature.

- A better understanding of the precipitation and dynamical context (micro-scale meteorology, vertical atmospheric structure) of these observations is crucial to analyze the atmospheric evolution.

All the above issues are crucial since they are linked to scientific questions related to atmospheric composition, pollution and climate, and their time evolution. CO-PDD also has the objective of providing quality data for model validations and developments (i.e., parameterization for example), as well as for validating satellite remote sensing retrievals.

\section{French and international structuration}

The CO-PDD site has the dual objective of being a research platform opened to scientists worldwide and a site operated in the framework of national and international networks. 


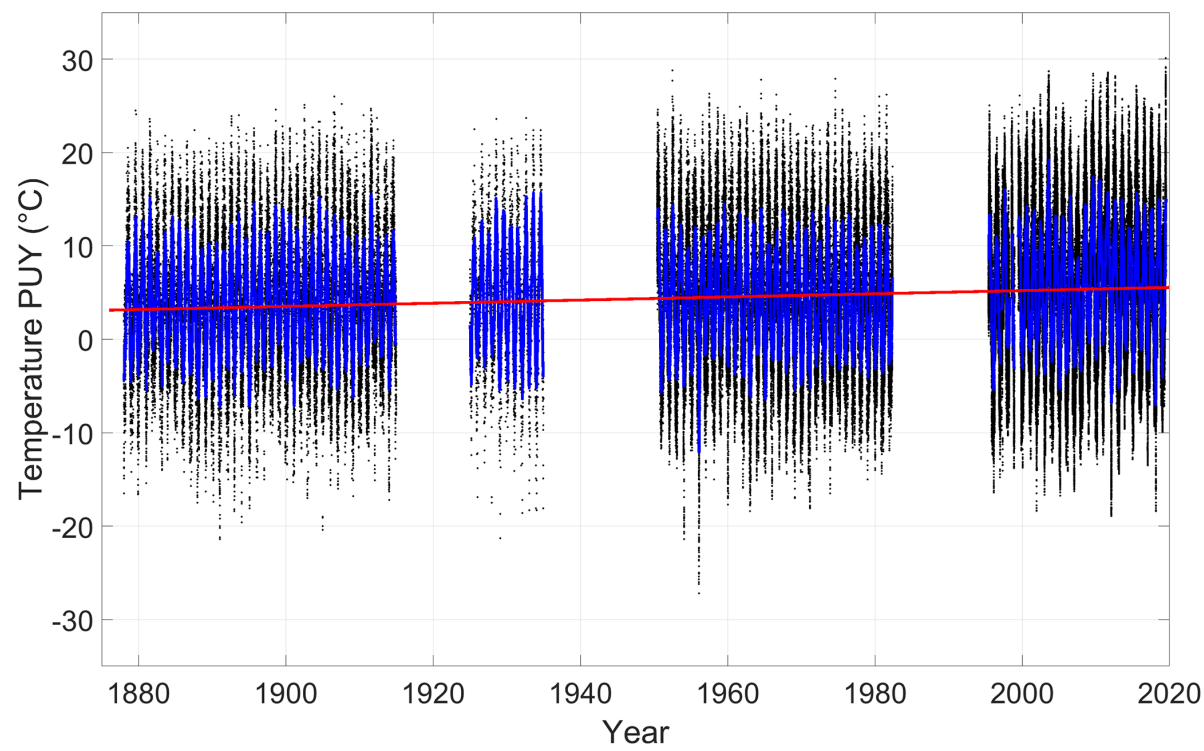

Figure 4. Long series of temperature at the PUY station. The hourly means are in black, the monthly means are in blue and the linear regression line is in red (slope: $+1.4 \pm 0.7^{\circ} \mathrm{C}$ per century).

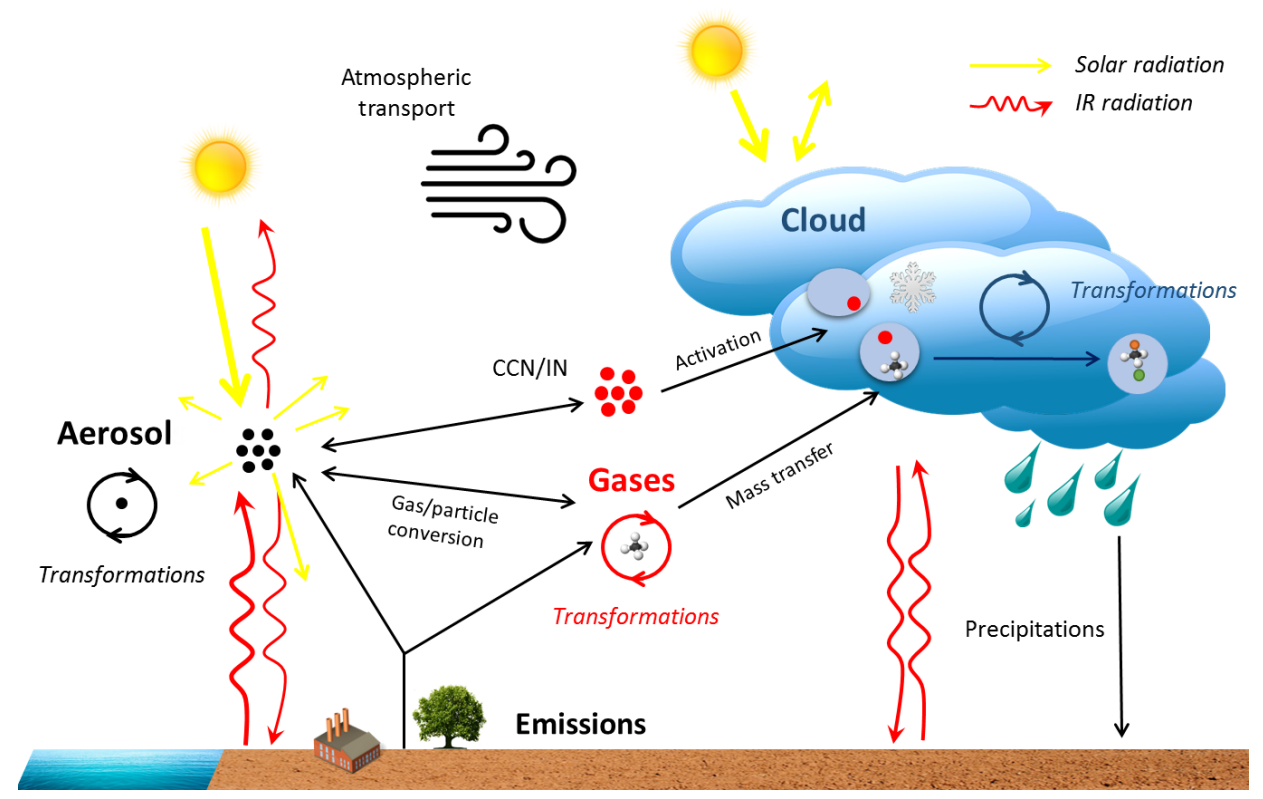

Figure 5. Schematic representation of atmospheric processes linking aerosol particles, clouds, precipitation, and radiation.

The most significant investments (construction and scientific equipment) have been made through regional strategic development of the Auvergne Region (now Auvergne-RhôneAlpes) and local authorities (department of puy-de-Dôme, Clermont-Ferrand Métropole). Research institutions (CNRSINSU, CNES, IRSN) and the University Clermont-Auvergne also provided substantial support but, as for many research infrastructures, availability of regional funding has been essential.
Beneficiaries from investment funds are the core research institutes operating at the site on a continuous basis: the observatory (OPGC) and the research laboratory (LaMP) for research investigations. The local research framework, the Environmental Research Federation (FRE) (Clermont Auvergne University), has initiated innovative and crossdisciplinary programs involving the ICCF ("Institute of Chemistry, Clermont-Ferrand") laboratory focusing on interactions between biodiversity and physico-chemical processes in the atmosphere. 
At national level, the site is recognized as a national observation facility by CNRS-INSU (Institut National des Sciences de l'Univers) in the framework of national infrastructures or services such as ACTRIS-France (Aerosol Cloud and Trace gases Research Infrastructure) grouping activities of AERONET-Photons (AEROsol RObotic NETwork), CLAP (CLimate Relevant Aerosol Properties), ICOS-France (Integrated Carbo Observation System), OPERA (Permanent observatory of the radioactivity), and RENAG (REseau NAtional GNSS permanent). CO-PDD is identified by the French national space agency (CNES) as a key facility for calibration/validation of space-borne sensors. CO-PDD also hosts internal observation services of OPGC, for reactive gases (PUY-GAZ) and for in situ cloud properties (PUYCLOUD). CO-PDD has also been involved in a lot of operations connected to research funded under short-term research programs obtained either through the CNRS research program, the National Agency for Research (ANR), or the European Union under the FP4, FP5, FP6, and H2020 projects.

CO-PDD is indeed active in the international dimension of the structures described previously in the national context, such as ICOS and ACTRIS (with the ID of PUY). CO-PDD contributes to different networks, either research- or policyoriented and organized at national and international levels: AERONET, EARLINET (European Aerosol Research LIDAR Network), EMEP as part of the Convention on longrange Transport of pollutants in Europe, E-Profile of EUMETNET, and GAW (Global Atmosphere Watch). PUY was labeled as a GAW regional station in 2012 and then the GAW global station in 2014. The station is the thirtieth in the world to receive this international recognition and the first in Metropolitan France.

CO-PDD participates in the transnational access program, which hosts intensive measurement campaigns carried out by foreign scientific teams. For example, instrumental intercomparisons of sensors measuring the microphysical properties of liquid clouds have been conducted recently (Guyot et al., 2015), but also campaigns to study aerosol-ice crystal interactions (PICNIC campaign, October 2018) or greenhouse gas spatial distributions (MAGIC campaign, June 2019; see AERIS, 2020b). The data regularly produced by CO-PDD are frequently used for European aerosol phenomenology studies, such as, for example, the study of the chemical (Putaud et al., 2004) and scattering (Pandolfi et al., 2018) properties of atmospheric aerosol particles from ACTRIS sites, including PUY or new particle and SOA formation (Dall'Osto et al., 2018). The data of the wind profilers are processed inside the E-Profile network and assimilated as such in the global model of the European Centre for MediumRange Weather Forecasts (ECMWF).

\section{Technical description of observation systems}

This section presents an overview of in situ and remote sensing instruments that characterize the various atmospheric compartments (aerosol particles, gases, and clouds). Instruments providing the meteorological context and radionuclides are described in the two last subsections.

\subsection{Aerosol}

\subsubsection{In situ}

After preliminary measurements done during the CIME experiment (Laj et al., 2001), PUY has been increasingly instrumented with in situ aerosol measurements. Specific inlets for aerosol particle sampling also under cloudy conditions have been deployed. The upper size cut of the whole air inlets (WAIs) is at least $30 \mu \mathrm{m}$ (at a maximum wind speed of $7 \mathrm{~m} \mathrm{~s}^{-1}$ ), allowing the sampling of a large fraction of cloud droplets (Fig. 6a). These cloud droplets are quickly evaporated in the inlet and then sampled by a suite of aerosol instrumentation within the station. Except for (N)AIS and PSM, all the instruments described here are operated behind a WAI. In contrast, (N)AIS and PSM, which are further described below, are dedicated to the monitoring of newly formed aerosol particles with diameters less than $10 \mathrm{~nm}$ and are thus located on the roof of the station where they sample through a shorter inlet $(\sim 30 \mathrm{~cm}$, non-heated) to limit diffusion losses.

\section{Particle size distribution}

Since 2005, a suite of instruments has progressively equipped the PUY station to monitor particles as well as ion size distributions over a broad size range, from a few nanometers up to a few tens of micrometers. Particle size distribution in the range between 10 and $400 \mathrm{~nm}$ has been measured at PUY since 2005 using a custom-built scanning mobility particle sizer (SMPS). SMPS inversion is made with the szdist algorithm developed at LaMP and available online (Picard, 2020). The inversion assumes a theoretical transfer function for the differential mobility analyzer (DMA) and takes into account the condensation particle counter (CPC) efficiency and the charge equilibrium state. It also includes multiple charge correction and accounts for diffusion losses in the instrument. Data quality is regularly checked during intercalibration procedures and inter-comparison workshops, initially conducted in the framework of the EUSAAR project (European Supersites for Atmospheric Research) and since 2011 within the ACTRIS project (Wiedensohler et al., 2012). The supermicronic fraction of the particle size distribution $(0.3$ to $20 \mu \mathrm{m})$ is measured at PUY with an optical particle counter (OPC, Grimm model 1.108).

The Air Ion Spectrometer (AIS, Airel Ltd., Mirme et al., 2007) and Neutral cluster and Air Ion Spectrometer (NAIS, Airel Ltd., Manninen et al., 2016; Mirme and Mirme, 2013) 
(a) INLET

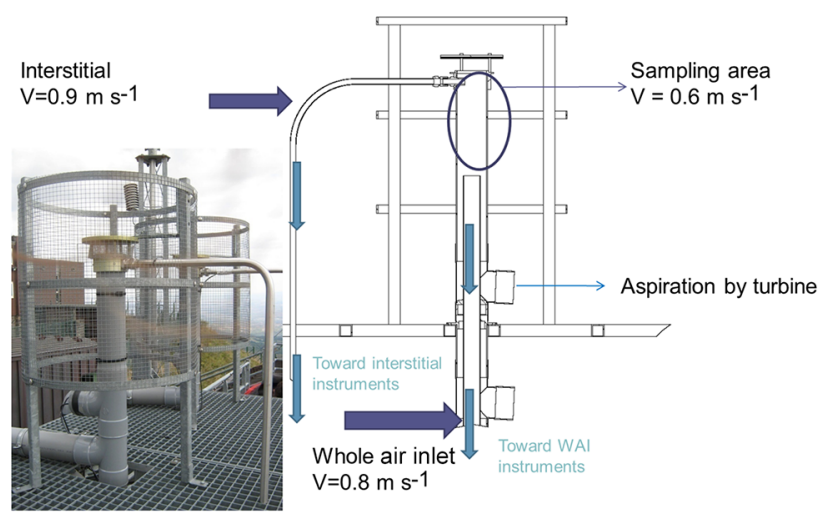

(c) TRAIN INSTRUMENTATION

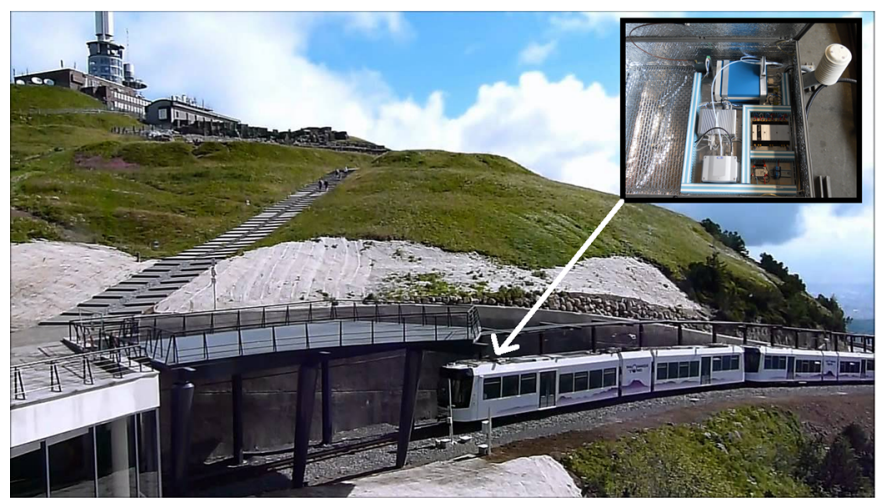

(b) AEROVOCC

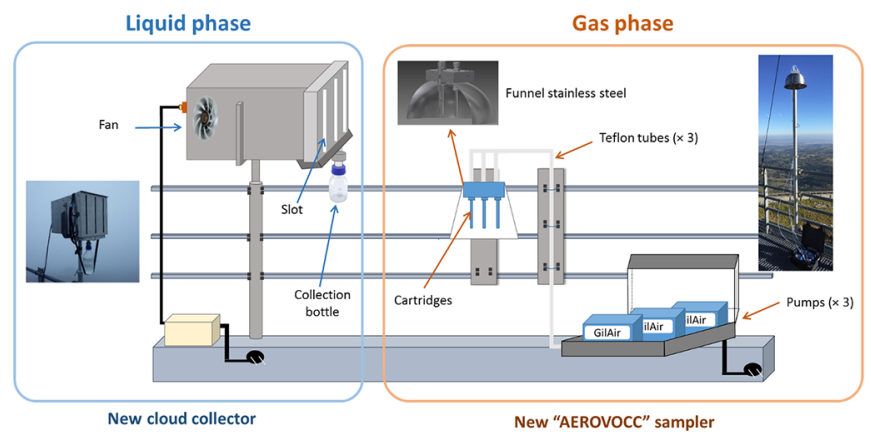

(d) LIDAR

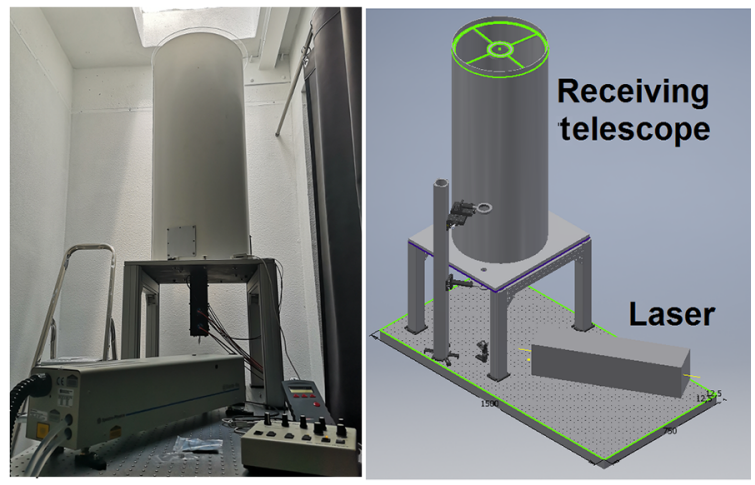

(e) WIND TUNNEL

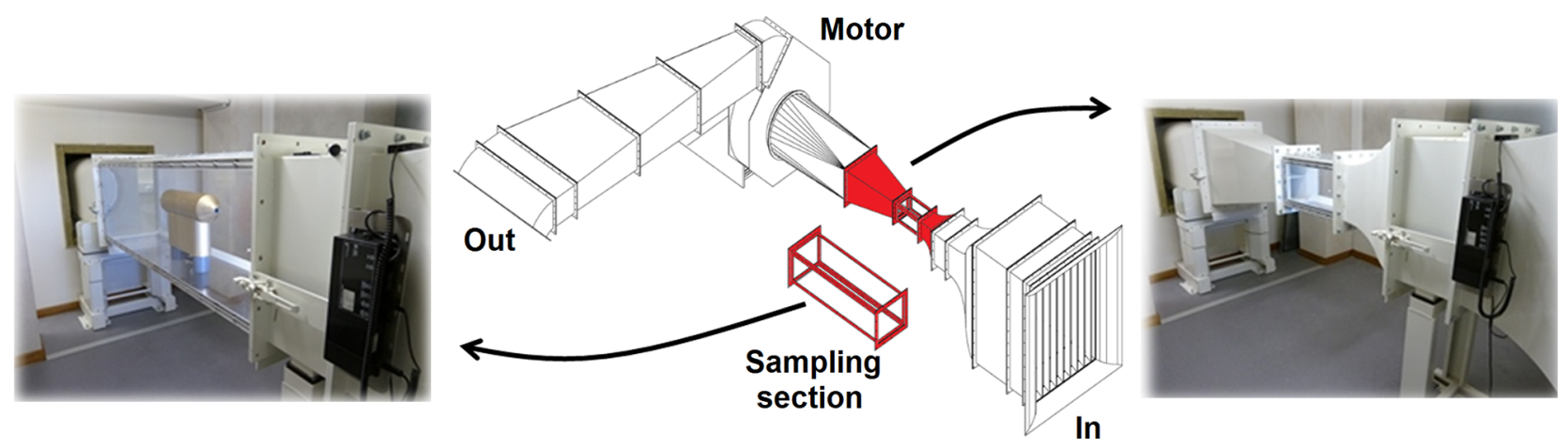

Figure 6. Examples of instrumental development. (a) Inlet for gas and aerosol sampling; (b) AEROVOCC: in situ multiphasic VOC sampling system, (c) tourist train instrumentation, (d) LIDAR COPlid development, and (e) wind tunnel. 
comprise two identical cylindrical DMAs which allow simultaneous measurement of positive and negative ions. Each analyzer operates with high flow rates (sample $30 \mathrm{~L} \mathrm{~min}^{-1}$, sheath $90 \mathrm{~L} \mathrm{~min}^{-1}$ ) in order to reduce diffusion losses in the sampling lines and further ensure a significant signal-tonoise ratio, even when ion concentrations are low. In addition to this so-called "ion mode", NAIS allows particle sampling in the same manner as the ion measurement, except that in the "particle mode", particles are first unipolarly charged by ions produced by a corona discharge. Each measurement cycle is followed by an offset cycle.

(N)AIS have been operated discontinuously at PUY since 2007 to document the lower end of the aerosol size range. They both provide ion size distributions in the range 0.8 $42 \mathrm{~nm}$ in normal temperature and pressure conditions (NTP), and NAIS allows additional monitoring of particle size distribution between $\sim 2$ and $42 \mathrm{~nm}$ in an NTP short inlet (length $30 \mathrm{~cm}$ ), approximately $2 \mathrm{~m}$ from the ground, and has been operated on the roof of the chalet since then $(11 \mathrm{~m}$ above the ground). Good consistency was observed between the data collected with the different AIS and NAIS successively deployed at the site (Rose et al., 2013). Two of our (N)AIS have also been involved in a wider inter-comparison (Gagné et al., 2011), showing that concentrations derived from NAIS measurements could vary from one instrument to the other by up to $10 \%$, which could be assimilated to the uncertainty in the measurement.

In order to complement NAIS observations and get further insight into the first stages of the formation process of neutral particles, measurement of particle concentration in the size range between $\sim 1$ and $2.5 \mathrm{~nm}$ was initiated in 2012 with a Particle Size Magnifier (PSM, Airmodus Ltd., Vanhanen et al., 2011). The PSM is a mixing-type instrument in which the activation of particles results from a rapid and turbulent mixing of the cooled sample flow and heated clean air saturated with diethylene glycol. Counting of the grown particles (mean diameter $\sim 90 \mathrm{~nm}$ ) is then performed with an ordinary CPC (TSI 3010). The activation of a cluster is mainly determined by its size, but its charge and chemical composition also affect the process (Kangasluoma et al., 2013). As a result, there is a systematic uncertainty in atmospheric PSM measurement related to the fact that calibrations of the instrument are performed in the lab with a limited number of known compounds. The instrument was initially operated behind a WAI and was later moved onto the roof of the chalet (September 2013), close to the (N)AIS, in order to decrease the length of the inlet (individual inlet $\sim 30 \mathrm{~cm}$ ) and further reduce the cluster loss in the sampling lines. PUY is among the first sites equipped with a PSM, and measurements from different sites have been recently compared (Kontkanen et al., 2017).

\section{Optical properties}

A Multi-Angle Absorption Photometer (MAAP) has been in operation at PUY since 2008. MAAP is an optical analyzer combining transmissometry and reflectometry (Petzold and Schönlinner, 2004). MAAP measures the radiation transmitted and backscattered by the particles impacted on a filter, using a two-flux radiative transfer model to minimize the influence of scattering during absorption measurements. Measurements provided by the instrument are soot carbon (BC) concentrations, from which the absorption coefficient can be traced by multiplying the $\mathrm{BC}$ concentration by the specific absorption coefficient $\left(6.6 \mathrm{~m}^{2} \mathrm{~g}^{-1}\right)$.

The TSI 3563 nephelometer measures the scattering of light from a laser source by aerosols and ice crystals. This light is detected at several wavelengths $(450,550$, and $700 \mathrm{~nm}$ ) at different angles by two optoelectronic sensors rotating around the sampling volume. This instrument provides integrated measurement of scattered light for angles between 7 and $170^{\circ}$ and backscattered between 90 and $170^{\circ}$. The nephelometer has been in operation at PUY since June 2006. The intersection of the particles with the beam produces a diffuse light at the level of the sampling volume, whose analysis makes it possible to obtain the scattering and extinction coefficients and the asymmetry factor of the diffusing elements (aerosols, ice crystals). The combination of the MAAP and the nephelometer makes it possible to calculate the simple scattering albedo $\omega_{0}$.

\section{Chemical properties}

For online measurements an aerosol chemical speciation monitor with a time of flight mass spectrometer (ACSM-ToF) is installed and has been operating at PUY since 2015. This instrument is capable of measuring the chemical composition of the submicron non-refractory fraction of the organic and inorganic species $\mathrm{NO}_{3}^{-}, \mathrm{SO}_{4}^{2-}, \mathrm{NH}_{4}^{+}$, and $\mathrm{Cl}^{-}$(Fröhlich et al., 2013). This instrument provides a continuous measurement of aerosol chemical properties with a time resolution from 10 to $30 \mathrm{~min}$. The instrument response is determined through calibrations with $300 \mathrm{~nm}$ ammonium nitrate particles. These aerosols are generated from solutions of $0.005 \mathrm{M}$ ammonium nitrate. Aerosols are atomized and then dried to a humidity of $<30 \%$ before passing into a differential mobility analyzer to select the size (Freney et al., 2019; $\mathrm{Ng}$ et al., 2011).

Day and night filters are sampled weekly for organic and elementary carbon (OC/EC) and major ion measurement. Quartz filters are used to analyze EC/OC with a Sunset analyzer. Cations (sodium, ammonium, potassium, magnesium, and calcium) are analyzed with a Dionex ICS-1500 chromatograph. Concentrations of major water-soluble anions (chloride, nitrate, sulfate, and oxalate) are determined with a Dionex IC25 chromatograph. 
Both the ToF-ACSM and offline filter (OC/EC) analysis methods are regularly checked through calibration and intercomparison at the European center of aerosol calibration (ACTRIS, 2020), specifically at the aerosol chemical monitor calibration center for the ToF-ACSM (Freney et al., 2019; Crenn et al., 2015) and at the Joint Research Center (JRC), Ispra, for OC/EC (Cavalli et al., 2010).

\section{Hygroscopic properties}

CCN measurements were initiated at PUY in 2011 with a miniature continuous-flow streamwise thermal gradient $\mathrm{CCN}$ chamber (CCNc) (Roberts and Nenes, 2005). The ability of aerosol particles to form a cloud droplet is determined using a cloud condensation nuclei chamber $(\mathrm{CCNc})$. Monodisperse aerosol particles (selected using a DMA) are introduced in the $\mathrm{CCNc}$ growth column, where they are surrounded by a clean humidified sheath flow. Growth tube walls are continuously wetted with water and the obtained supersaturation is determined by the aerosol flow rate and the column temperature gradient, which can both be varied to provide saturations of $0.1 \%$ to $0.5 \%$. The $\mathrm{CCN}$ number concentration is determined by means of an optical detector at the end of the growth tube, and, for a given size, the activated fraction of the aerosol is inferred from the particle concentration measured by a condensation particle counter (CPC, TSI 3010) operated after the DMA and in parallel to the CCNc. From 2012 onwards, the DMA and the CCNc have been arranged in a single instrument designed at LaMP called SCANOTRON, which provides similar measurement to the initial setup but is more compact and eases measurement procedures as well as data analysis. Calibrations of the $\mathrm{CCNc}$ are performed on a regular basis using ammonium sulfate and sodium chloride.

The hygroscopicity of aerosols is measured with the Hygroscopic Tandem Differential Mobility Analyzer (HTDMA), an instrument designed at LaMP composed of two DMAs in a tandem arrangement (Villani et al., 2008). This system makes it possible to know the increase in diameter caused by humidity: the hygroscopic growth factor, linked to the chemical composition of the aerosol particles. Ammonium sulfate calibrations and dry scans are performed periodically. HTDMA participated in various international intercomparisons in the framework of the European EUSAAR project (Duplissy et al., 2009) and showed, during the ammonium sulfate calibration, that the uncertainty of the measured hygroscopic growth factor was $2 \%$.

\subsubsection{Remote sensing}

\section{Aerosol profiles}

A Rayleigh-Mie-Raman lidar system has been in operation at Cézeaux since 2008. This lidar is dedicated to the observation of aerosol particles, but also of cirrus clouds and water vapor. It was designed by the Gordien Strato com- pany and built by the Raymetrics company in 2007 . The laser source is a Quantel CFR-400 operating in the ultraviolet range $(355 \mathrm{~nm})$. The receiving telescope is a $400 \mathrm{~mm}$ Cassegrain telescope. The receiving box splits the receiving light into four different channels, two elastic channels with polarization splitting (parallel and cross) and two inelastic channels at 387 and $408 \mathrm{~nm}$ for nitrogen and water vapor Raman scattering. Due to the biaxial configuration of the lidar system, the laser beam overlaps completely the field of view of the telescope at about $1000 \mathrm{~m}$ above the lidar and is in a partial overlap at about $500 \mathrm{~m}$. Since 2013, the operation has been automatized to operate continuously the elastic channels during day and night and the inelastic channels during night only for appropriate conditions. The lidar produces profiles of backscatter signal, from which level 2 data are calculated: water vapor mixing ratio, and aerosol / cirrus extinction and backscattering coefficient (Fréville et al., 2015). In 2018, the COPLid improvement project (Fig. 6d) made it possible to change the laser source for a more powerful laser, to optimize the infrastructure of the lidar inside the building of the university, and to add acquisition channels at 532 and $1064 \mathrm{~nm}$ wavelengths for aerosol-cirrus measurements. In this up-to-date configuration, the Cézeaux lidar system reaches the optimal configuration requested by EARLINET standards, allows us to retrieve aerosol microphysics, and is more appropriate to compare aerosol and cloud products with present and future satellite retrievals such as CALIOP (Cloud-Aerosol LIDAR with Orthogonal Polarization, since 2006) onboard CALIPSO and ATLID (Atmospheric LIDAR) onboard EarthCare (Earth Clouds, Aerosols and Radiation Explorer, launch planned in 2021).

\section{Aerosol vertical columns}

A CIMEL CE318 automatic sun-tracking photometer has been in operation at Cézeaux since 1999 in collaboration with the LOA (Laboratoire d'Optique Atmospherique, Lille, France) and in the framework of the AERONET international network (Holben et al., 1998). The photometer measures the solar radiance in five spectral bands: 440, 670, 870, 936, and $1020 \mathrm{~nm}$. The spectral band of $870 \mathrm{~nm}$ is measured from three polarized channels of $120^{\circ}$. This instrument provides the integrated optical thickness of atmospheric aerosols and the Angström coefficients calculated from the direct solar radiance. It can also retrieve the volume size distribution (fine and coarse modes) through multi-angular solar radiance measurements with an inversion algorithm detailed in Dubovik and King (2000). 


\subsection{Greenhouse and reactive trace gases}

\subsubsection{In situ}

\section{Greenhouse gases}

Greenhouse gas $\left(\mathrm{CO}_{2}, \mathrm{CH}_{4}, \mathrm{~N}_{2} \mathrm{O}\right.$, and $\left.\mathrm{SF}_{6}\right)$ measurements in November 2000 were part of the SNO-RAMCES/ICOSFrance French monitoring program (Broquet et al., 2013; Lopez et al., 2015; Ramonet et al., 2010; Sturm et al., 2005). Three types of analyzers were used: non-dispersive infrared instruments (NDIR, LICOR-6251 from 7 November 2000 to 20 November 2007; LICOR-6252 from 21 November 2007 to 3 April 2011); gas chromatography (GC, Agilent HP6890N from July 2010 to April 2015); and cavity ringdown spectrometers (CRDS) commercialized by PICARRO (G1301/no. 76 from 3 April 2012 to 2 February 2015; G2401/no. 285 from 2 February 2015 to 25 August 2016; G2401/no. 473 since 25 August 2016).

The automated gas chromatograph (GC) system (Agilent HP-6890N) was equipped with a flame ionization detector (FID) with a nickel catalyst for $\mathrm{CH}_{4}$ and $\mathrm{CO}_{2}$ detection and a micro-electron capture detector $(\mu \mathrm{ECD})$ for $\mathrm{N}_{2} \mathrm{O}$ and $\mathrm{SF}_{6}$ detection (Lopez et al., 2015). Two working standards, each calibrated against the WMO scale, were injected every $30 \mathrm{~min}$ to correct for instrumental drifts. Data quality control was ensured through hourly injections of a target gas, and regular instrumental calibrations were performed using three WMO calibrated compressed air cylinders. Repeatability is $0.1 \mathrm{ppm}$ for $\mathrm{CO}_{2}, 1.2 \mathrm{ppbv}$ for $\mathrm{CH}_{4}, 0.3 \mathrm{ppbv}$ for $\mathrm{N}_{2} \mathrm{O}$, and $0.06 \mathrm{pptv}$ for $\mathrm{SF}_{6}$.

Following the ICOS standard protocol, the Picarro instruments are calibrated upon a suite of four calibrated compressed air cylinders provided by the ICOS calibration center (calibrated against the WMO scale) every 2 to 4 weeks, and quality control of the data is ensured by regular analysis of two target gases (with known and calibrated concentrations): one short-term target gas analyzed for $30 \mathrm{~min}$ at least twice a day and one long-term target gas analyzed for $30 \mathrm{~min}$ during the calibration procedure (enabling a long-term -10 years at least - data quality control).

For all the instruments, ambient air is pumped from the roof platform through $10 \mathrm{~m}$ long dekabon tubing and dried via a glass trap cooled by a cryocooler at $-60^{\circ} \mathrm{C}$ prior to injection into the analyzer. The drying system was suppressed in August 2016 with the installation of the CRDS, allowing measurement of atmospheric moisture content. The Picarro analyzer enables a measurement of atmospheric moisture content, which is used to correct the measured greenhouse gas (GHG) concentrations.

The GC setup allows analysis of approximately five atmospheric samples per hour, whereas the infrared instruments (NDIR, CRDS) allow continuous measurements (minute or hourly averages are calculated from raw data measured every $2.5 \mathrm{~s}$ ).
In addition to the continuous measurements, glass flasks are weekly sampled for $\delta \mathrm{O}_{2} / \mathrm{N}_{2}$ and $\mathrm{CO}_{2}$ analysis at the Physics Institute, University of Bern (Sturm et al., 2005; Valentino et al., 2008), and for $\mathrm{CO}_{2}, \mathrm{CH}_{4}, \mathrm{CO}, \mathrm{N}_{2} \mathrm{O}, \mathrm{SF}_{6}$, and $\mathrm{H}_{2}$ measurements at the LSCE. Isotopic content measurements of $\mathrm{CO}_{2}\left(\delta^{13} \mathrm{C}\right.$ and $\left.\delta^{18} \mathrm{O}\right)$ were also performed on the flask samples at the LSCE until 2016. $\mathrm{CO}_{2}$ and $\mathrm{CH}_{4}$ measurements at PUY were certified by a GAW audit in April 2016. During this audit, the station also hosted the ICOS mobile laboratory which is circulating within the ICOS network in order to evaluate the compliance with the ICOS protocols.

\section{Ozone measurement}

Since 1995 a UV photometric analyzer (from 1995 to 2003: a model commercialized by Environment SA; from 2003 to 2017, a Thermo Scientific model TEI 49c; since 2017, a Thermo Scientific model TEI 49i) has provided ambient measurements of concentrations of ozone $\left(\mathrm{O}_{3}\right)$. Model $49 \mathrm{i}$ uses a dual-cell photometer, the concept adopted by the National Institute of Standards and Technology as the principle technology for the national ozone standard. It measures the amount of ozone from $0.05 \mathrm{ppb}$ concentrations up to $200 \mathrm{ppm}$ (response time of $20 \mathrm{~s}$, precision of $1 \mathrm{ppb}$ ). The calibration is performed every 3 months using a dynamic standard mixture generator (ANSYCO), which is certified and traceable to the national calibration chain for air quality. Therefore, it has been checked in the framework of a GAW audit in 2014.

\section{$\mathrm{NO}_{x}$ and $\mathrm{SO}_{2}$ measurement}

The measurement of $\mathrm{NO}_{x}\left(\mathrm{NO}+\mathrm{NO}_{2}\right)$ has been deployed at PUY since 2003 using an analyzer by chemiluminescence (from 2003 to 2018, a Thermo scientific model TEI 42cTL; since 2019, a Thermo Scientific model 42iTL). The instrument measures directly $\mathrm{NO}$ and indirectly $\mathrm{NO}_{x}$ after conversion into NO. Until 2012, the converter was a molybdenum one which is not selective for $\mathrm{NO}_{2}$ since its also converts part of other $\mathrm{NO}_{y}$ (especially $\mathrm{HONO}, \mathrm{HNO}_{3}$, and PAN). Since December 2012, a Blue Light Converter (BLC) specific for the selective conversion of $\mathrm{NO}_{2}$ has equipped the analyzer. Tendencies have been analyzed separately for $\mathrm{NO}_{2}$ during the period 2003-2012, $\left(\mathrm{NO}_{2}+\right.$ part of $\mathrm{NO}_{y}$ converted) and 2012-present, which is real $\mathrm{NO}_{2}$. Since then, the $\mathrm{NO}_{x}$ measurement protocol has followed the ACTRIS standard operation procedure. Data sets are validated each year and are available on the EBAS database website (http://ebas.nilu.no, last access: 10 June 2020). $\mathrm{SO}_{2}$ concentrations are measured since 2003 with a Thermo Scientific model 43i, changed for a Thermo Scientific model 43iTL in 2017. NO, $\mathrm{NO}_{2}$ and $\mathrm{SO}_{2}$ are calibrated every month with reference mixtures obtained from the dynamic dilution of working standards (at $5 \mathrm{ppm}$ ), which are checked every years with traceable standards. The $\mathrm{NO}_{x}$ instrument took part in a side-by-side intercomparison 
held in Hohenpeissenberg in 2012 in the framework of the ACTRIS program.

\section{VOC measurement}

Active sampling on sorbent cartridges has been performed at PUY since 2010 to measure volatile organic compounds (VOCs). For this, a smart automatic sampling system (SASS) developed by TERA Environment is used. Gaseous compounds are sampled at approximately $6 \mathrm{ma.g.l}$, using a Teflon sampling line, and then trapped into a Tenax ${ }^{\circledR}$ sorbent cartridge at a flow rate of $100 \mathrm{~mL} \mathrm{~min}^{-1}$. The time duration of sampling varies between $40 \mathrm{~min}$ and $2-3 \mathrm{~h}$ and allows the trapping of major anthropogenic and biogenic VOCs: $\mathrm{C}_{5}-\mathrm{C}_{14} n$-alkanes, alkenes, terpenoids, and aromatic compounds. The analytical device used for the cartridge analysis consists of a gas chromatograph-mass spectrometer system (GC-MS, Perkin Elmer) connected to an automatic thermal desorber (Turbomatrix Perkin Elmer). Storage times for the cartridges are less than 3 months before analysis by GC-MS. Cartridges have Swagelok caps and are kept in a dark and cool room $\left(\sim 20^{\circ} \mathrm{C}\right)$ at the laboratory. The analytical conditions are described in other recent articles (Dominutti et al., 2019; Wang et al., 2020). Since September 2018, an online GC-FID (Gas Chromatography - Flame Ionization Detector) has been running at PUY for the online monitoring of nonmethane hydrocarbons (NMHCs) from $\mathrm{C} 2$ to $\mathrm{C} 10$. Air samples collected every $2 \mathrm{~h}$ at $25 \mathrm{~mL} \mathrm{~min}^{-1}$ during $40 \mathrm{~min}$ are dried through a semipermeable membrane (Nafion, Permapure Inc.) and introduced in a trap cooled by the Peltier effect. This system is an adaptation of the Perkin Elmer Turbomatrix coupled with the GC-FID 6890 from Agilent. VOC measurements follow the ACTRIS/GAW Standard Operating Procedures for sampling, calibrations, and data validation. PUY has participated in an inter-comparison exercise through a round-robin test (Hoerger et al., 2015).

\subsubsection{In situ measurements along the PUY slopes}

In 2012, the tourist train line called Panoramique des Dômes was opened and joined the base of the puy de Dôme to its summit. It has been equipped with a sampling platform containing an ozone analyzer (2B technology) and temperature, pressure, and humidity sensors (Fig. 6c). This information is used to follow the concentration gradient along the slope of the puy de Dôme and to determine the mixing layer height and the inversion temperature that occurs along the slope of the volcano.

\subsection{Cloud}

\subsubsection{In situ}

\section{Microphysical measurement}

Gerber PVM-100 is a ground-based scattering laser spectrophotometer for cloud droplet volume measurements and is manufactured by Gerber Scientific, Inc., Reston, Virginia. The laser light emitted at the wavelength $\lambda=0.780 \mu \mathrm{m}$ is dispersed by cloud droplets passing through the sampling volume of the $3 \mathrm{~cm}^{-3}$ probe. This light is collected by a lens system whose angle varies from 0.25 to $5.2^{\circ}$. The scattered light is converted into a signal which is proportional to the droplet density (or LWC) and the particle surface density (PSA) with a time resolution of $5 \mathrm{~min}$ (Gerber, 1984, 1991). It has been tested and inter-compared with other instruments during ACTRIS transnational access activities at PUY in May 2013 (Guyot et al., 2015).

\section{Cloud sampling}

Since 2001, cloud water sampling has been regularly performed at PUY using a dynamic one-stage cloud water impactor (Brantner et al., 1994), with a cut-off diameter of approximately $7 \mu \mathrm{m}$. Recently, a new cloud water collector was developed to increase the efficiency of collection (Fig. 6). Before sampling, the aluminum impactor is cleaned and sterilized by autoclave to allow micro-biological investigations. A fraction of the cloud water sample is filtered immediately after collection to eliminate microorganisms or particles, while another fraction is kept unfiltered for microbiological measurements. Different bio-physico-chemical parameters are determined systematically on cloud water sample filtered and non-filtered fractions. Some bio-chemical parameters are immediately measured on site from the fresh samples, while others can be performed later in the laboratory from stabilized and/or frozen samples. The measurements are used to evaluate the variability of the cloud water composition that depends on both season and air mass origin.

\section{Cloud chemical measurements}

The $\mathrm{pH}$ is determined immediately after sampling. Main inorganic cations $\left(\mathrm{Na}^{+}, \mathrm{NH}_{4}^{+}, \mathrm{K}^{+}, \mathrm{Mg}^{2+}, \mathrm{Ca}^{2+}\right)$ and anions $\left(\mathrm{Cl}^{-}, \mathrm{NO}_{3}^{-}, \mathrm{SO}_{4}^{2-}, \mathrm{PO}_{4}^{3-}\right)$ as well as short chain carboxylic acids (formate, acetate, succinate, oxalate) are measured by ion chromatography (IC). An analyzer measuring the total organic carbon concentration is used to estimate the organic matter present in cloud water. Hydrogen peroxide $\left(\mathrm{H}_{2} \mathrm{O}_{2}\right)$, a strong oxidant in the cloud water, is determined by the spectrofluorimetric quantification method (Li et al., 2007). The concentration of $\mathrm{Fe}(\mathrm{II})$ and $\mathrm{Fe}(\mathrm{III})$, a key parameter for the cloud water oxidative capacity evaluation (Deguillaume et al., 2005), is determined by a spectrophotometric method after chemical complexation (Stookey, 1970). 
More recently, the analysis of the chemical composition of the cloud waters sampled at the PUY was improved with the quantification of 16 amino acids (AAs) determined using a new complexation method coupled with high-performance liquid chromatography (HPLC) (Bianco et al., 2016); the concentrations of 33 metal elements have been determined using inductively coupled plasma mass spectrometry (ICPMS) (Bianco et al., 2017). The oxidative capacity of the cloud water has also been evaluated following the hydroxyl radical $\left(\mathrm{HO}^{*}\right)$ formation rates during the irradiation of cloud waters under sun-simulated radiation (Bianco et al., 2015).

Finally, ultrahigh-resolution mass spectrometry was recently used to get a better identification of the dissolved organic compounds. Using the GCxGC-HRMS technique, more than 100 semi-volatile compounds were detected and identified (Lebedev et al., 2018). Among them, phenols and phthalates that are strong pollutants were quantified. Ultrahigh-resolution Fourier-transform ion cyclotron resonance mass spectrometry (FT-ICR MS) was also used to identify a wide spectrum of organic compounds (up to 5000 assigned molecular formulas) that have been shared into several classes depending on their $\mathrm{H} / \mathrm{C}$ and $\mathrm{O} / \mathrm{C}$ ratio (Bianco et al., 2018, 2019a).

\section{Cloud biological measurements}

Since 2003, microorganisms in cloud waters and their activity have also been investigated (Amato et al., 2005; Vaïtilingom et al., 2012). Each cloud water sample is collected under sterile conditions, and microbiological parameters such as biomass, biodiversity, and biological activity are measured. Total cells are counted using epifluorescence microscopy (before 2010) or flow cytometry. Bioluminescence is used to quantify adenosine triphosphate (ATP) as a marker of the whole metabolic activity. Living cultivable microorganisms (bacteria and fungi) are generally investigated as well by platting samples on nutritive media and then isolated and identified against databases by $16 \mathrm{~S}$ rRNA gene sequencing (Amato et al., 2007b; Vaïtilingom et al., 2012). This allows the isolation of microorganisms from the cloud water and their interaction with atmospheric chemical compounds (Amato et al., 2007a). Now more than 1000 microbial strains are available for in-lab experiments and for biotechnological applications. Recently, molecular biological techniques based on DNA and RNA have been developed to study microbial diversity and activity in clouds (Amato et al., 2017, 2019).

\subsubsection{Wind tunnel}

Located at PUY, the wind tunnel is a unique national facility that operates under natural atmospheric conditions (cloudy conditions or not). It was built and installed in 2010 during the renovation of the station. The wind tunnel (Fig. 6e) has an open circuit configuration with an entrance located on the western side of the chalet facing prevailing winds. The threephase electric motor $(132 \mathrm{~kW})$ generates a variable air flow up to $17 \mathrm{~m}^{3} \mathrm{~s}^{-1}$ (variable and controlled speed). Depending on the type of application, two interchangeable rectangular section tubes allow different maximum air velocity, depending on the objective: the tube with a section of $250 \times 320 \mathrm{~mm}$ and a length of $600 \mathrm{~mm}$ allows a maximum speed $120 \mathrm{~m} \mathrm{~s}^{-1}$; the section of $540 \times 640 \mathrm{~mm}$ and of length of $2000 \mathrm{~mm}$ allows a maximum speed $52 \mathrm{~m} \mathrm{~s}^{-1}$.

The wind tunnel offers several applications:

- for scientific issues: development of original methodologies and equipment for cloud and aerosol in situ aircraft observations for studies on cloud-chemistryclimate interactions;

- for technological issues: test and validation of airborne instruments; the wind tunnel was used for example in May 2013 for an evaluation campaign of optical sensors for cloud microphysical measurements (Guyot et al., 2015). The wind tunnel is integrated in validation procedures of airborne microphysics probes; and

- for industrial applications: the wind tunnel has been used for studies of aircraft elements in icing conditions in the context of flight certifications or at the request of the aviation industry.

\subsection{Precipitation, meteorology, dynamics}

CO-PDD has been a sustainable site for the observation of precipitation at the scale of the urban basin of ClermontFerrand since 2006. For this purpose, a combination of radars is operating at different frequencies in the $\mathrm{K}$ and $\mathrm{X}$ bands, providing the size spectra of hydrometeors and spatial distribution of reflectivity as well as optical disdrometers and a network of rain gauges. The dynamical and meteorological context is characterized using in situ and remote sensing measurement of wind, temperature, and humidity.

\subsubsection{In situ}

\section{Meteorological parameters}

The meteorological context of CO-PDD is completed by ground-level meteorological stations and sonic anemometers operating continuously at all the measurement sites of COPDD. Near-ground humidity measurements have been available at Cézeaux since 2002 and at PUY since 1995. The meteorological sensors of the Cézeaux and puy de Dôme sites are Vaisala HMP45 (HUMICAP 180 humidity sensor and PT100 temperature sensor). The accuracy and other technical specifications are available on the Vaisala manufacturer's website (https://www.vaisala.com/sites/default/files/ documents/HMP45AD-User-Guide-U274EN.pdf, last access: 10 June 2020). 


\section{Raindrop size distribution}

Parsivel $^{2}$ is an optical disdrometer commercialized by the OTT Company and designed to individually measure the diameter and fall speed of the raindrops. This measurement is made when drops intersect a laser beam with a final sampling surface of $54 \mathrm{~cm}^{2}$. The diameter of droplets is estimated from the decrease in the intensity of the laser beam received by a photoelectric diode, and the fall speed is estimated by the time taken by the drop to cross the beam. Two Parsivel ${ }^{2}$ instruments are deployed at Aulnat and Opme, in complement with a network of classical rain gauges and in conjunction with MRRs (Micro Rain Radars) in order to provide continuous DSD profiles from the ground up.

\section{Full sky imager and webcam cameras}

Two CO-PDD webcams are in operation, one at Cézeaux looking towards PUY and the other at PUY looking towards the Clermont-Ferrand area. These are Axis P1343 highperformance cameras and are widely used in daytime and nighttime video surveillance. They capture a $600 \times 800$ pixels image every $10 \mathrm{~min}$ in the compressed JPEG format. More technical details on the cameras are available on the Axis manufacturer's website (https://www.axis.com/en, last access: 10 June 2020). In addition, an full sky imager has been in operation at Cézeaux since December 2015. This is an EKO SRF-02 camera, a fully automatic imaging system that captures 2 mega-pixel JPEG images of the total sky every 2 min at two different time exposures. When sky images are captured, cloud fraction is automatically calculated by the software, which gives much flexibility and functions to define the area of interest by horizon masking. The SRF-02 is connected to a computer network through the standard Ethernet interface. The full sky imager is equipped with an air pump and a drying cartridge. All sky images are processed with the ELIFAN algorithm which aims at estimating the cloud cover amount (Lothon et al., 2019).

\subsubsection{Remote sensing}

\section{Rain spatial distribution}

A X-band local area weather radar is operated in order to provide 2-D reflectivity maps. The original system is a modified navigation radar designed by the University of Hamburg and the Max Planck Institute for Meteorology and has been operated in Clermont-Ferrand since the fall of 2006. The frequency of this system is $9410 \mathrm{MHz}$ and the current emitted peak power $24 \mathrm{~kW}$. The antenna is an off-set parabola with a diameter of $90 \mathrm{~cm}$ to define a suitable pencil beam for precipitation observation. Records are accumulated over successive rotations of the antenna which has a scan rate of 24 revolutions per minute. Another X-band radar system commercialized by the ELDES Company (WR-10 X) was purchased in 2011 and installed onboard a mobile trailer. This radar op- erates at the same frequency, with an emitted peak power of $9.5 \mathrm{~kW}$ and a $70 \mathrm{~cm}$ diameter center feed antenna. As opposed to the previous system which operates a plan position indicator (PPI) scan at a fixed pre-set elevation, the ELDES radar can perform multiple elevation volume scans as well as range height indicator (RHI) scans. The typical operation mode for the two radar systems corresponds to below 1 min time integration and below $100 \mathrm{~m}$ range resolution with a maximum range between 20 and $36 \mathrm{~km}$ according to experimental and weather conditions. These radar systems have been involved in the COPS (Convective Orographicallydriven Precipitation Study) (Hagen et al., 2011; Van Baelen et al., 2011; Wulfmeyer et al., 2011) and HYMEX (HYdrological cycle in Mediterranean Experiment) (Zwiebel et al., 2016) international campaigns. In 2019, due to technical problems, the older radar was removed from the Cézeaux platform and replaced with the ELDES system.

The two MRRs in operation at Opme and Aulnat are Kband $(24.1 \mathrm{GHz})$ vertical Doppler FMCW radars commercialized by the METEK Company. They allow the investigation of the vertical microphysical structure of precipitation. Measurements from the retrieved reflectivity and Doppler velocity profiles make it possible to reconstruct the profiles of rain rate and drop size distribution through drop sorting with the Atlas relationship between drop size and fall speed (Atlas et al., 1973), over 32 range gates with $100 \mathrm{~m}$ vertical resolution up to $3000 \mathrm{~m}$ every $10 \mathrm{~s}$. The spectral reflectivity is dynamically analyzed to estimate and remove the noise, and the attenuation is corrected along the path by using an improvement of the Hitschfeld and Bordan algorithm (Tridon et al., 2011). The peak power is $50 \mathrm{~mW}$, the sampling frequency is $125 \mathrm{kHz}$, and the antenna diameter is $60 \mathrm{~cm}$.

\section{Wind profiles}

Wind-profiling radars use the Doppler frequency shift of signals scattered from atmospheric turbulence to monitor wind profiles. One system has been operating at Opme in the VHF band (45 MHz) since 1999. The antenna field is made of two perpendicular sets of $60 \mathrm{~m}$ coaxial-collinear lines fed with or without fixed delay, enabling the radar beam to be successively pointed vertically, and in four oblique angles, depending on a control sequence. This allows the measurement of the time evolution of the horizontal and vertical wind profiles from 2 to $12 \mathrm{~km}$ a.s.1. with a vertical resolution of $375 \mathrm{~m}$ (Baray et al., 2017).

To complete the wind profile monitoring of the lower troposphere, a refurbished RADIAN prototype system has been in operation at Aulnat, near Cézeaux, since 2014. This profiler is based on the same principle as the VHF wind profiler, but it is operated in the UHF band. The micropatch antenna of $2.8 \times 2.8 \mathrm{~m}$ is controlled sequentially in five directions. That allows the measurement of the time evolution of the vertical and horizontal wind from 500 to $3300 \mathrm{~m}$ a.s.l. with a vertical resolution of $100 \mathrm{~m}$. 


\section{$\mathrm{H}_{2} \mathrm{O}$ profiles and columns}

As mentioned in Sect. 5.1.2, the lidar system in operation at Cézeaux is equipped with Raman channels for nitrogen and $\mathrm{H}_{2} \mathrm{O}$, providing vertical profiles of water vapor from 1 to $10 \mathrm{~km}$ of altitude.

Since the 1990s, the GPS (Global Positioning System) has proven to be an autonomous, all-weather, and continuous system for the measurement of atmospheric water vapor (Bevis et al., 1992). The GPS, GLONASS (GLObal NAvigation Satellite System), and GALILEO satellite constellation signals are collected by ground-based receivers. With respect to propagation in a vacuum, the signal traveling between a GPS satellite (altitude of $20200 \mathrm{~km}$ ) and a ground-based receiver is delayed by the atmospheric constituents (dry air and water vapor). The zenithal wet delay, due mainly to water vapor abundance, can be estimated from the difference between the total atmospheric zenithal delay and its hydrostatic term, i.e., the zenithal hydrostatic delay, or so-called dry delay, which depends on the total weight of the atmosphere above. The zenithal wet delay is converted into the integrated water vapor column with a good accuracy, using surface temperature and empirical formulas (Bevis et al., 1992). GPS receivers are in operation at Cézeaux, PUY, and Opme. Set at different altitude levels, they allow the monitoring of the water vapor evolution in the different corresponding atmospheric layers sampled.

\subsection{Radionuclides}

Man-made and cosmogenic radionuclides attached to aerosols are studied as part of the French Observatoire Permanent de la Radioactivité (OPERA program) of the Institut de Radioprotection et de Sûreté Nucléaire (IRSN). Anthropogenic and naturally occurring radionuclides are monitored on a monthly basis in rainwater sampled at Opme. Aerosols have also been sampled on a weekly basis at PUY since 2005 and Opme since 2006. PUY is one of the two highest radionuclide monitoring stations in France.

Detection of radionuclides at trace levels requires a high sampling volume (several tens of liters) or collection surface ( 1 to $3 \mathrm{~m}^{2}$ ). The summit has been equipped with a highvolume sampler (maximum sampling rate of $700 \mathrm{~m}^{3} \mathrm{~h}^{-1}$ ) since 2010 and using an electret polypropylene fiber filter to ensure high collection efficiency (minimum of $95 \%$ for $30 \mathrm{~nm}$ diameter). Aerosol filters are analyzed by gamma spectrometry on low-background high-purity germanium (HPGe) detectors in an underground laboratory. Another cloud water collector is deployed at PUY to collect radionuclides. A Caltech-type cloud droplet sampler is used to collect high volume in order to exceed the detection limits. Up to $80 \mathrm{~L}$ can be sampled on a monthly basis. The sampler is equipped with heating rods to allow sampling in winter conditions using sampling-heating cycles. Radionuclide characterization at the PUY strengthens the European moni- toring of airborne radioactive contamination at high altitude as for instance at the Sonnblick, Jungfraujoch, or Zugspitze stations which play an important role in the knowledge of transboundary dispersion of radioactive plumes, such as after the Fukushima accident or during European-scale events of unexpected radionuclides in the atmosphere (Masson et al., 2016).

\section{Main scientific results}

\subsection{Trace gases}

An increase in anthropogenic GHG concentrations is observed in the atmosphere, leading to a modification of their natural cycles and to a strong increase in atmospheric radiative forcing. Accordingly, the concentrations of $\mathrm{CO}_{2}$ have regularly increased since the start of measurements at PUY (Fig. 7). The average $\mathrm{CO}_{2}$ mole fraction increased from $370 \mathrm{ppm}$ in November 2010 up to $410 \mathrm{ppm}$ in November $2018(+11 \%)$. This is consistent with observations at other locations (example: Mauna Loa $409.5 \mathrm{ppm}$, obtained at an altitude of $3400 \mathrm{~m}$ in the remote northern subtropics, November 2018). At the same time, the mean mole fraction of $\mathrm{CH}_{4}$ also increased from 1.850 to $1.950 \mathrm{ppm}$ during the same period (not shown). A 3-year (July 2010-July 2013) analysis of GHG measurements was performed using a gas chromatograph system located at PUY (Lopez et al., 2015). The analysis of the 3-year atmospheric time series revealed how the planetary boundary layer height drives the concentrations observed at PUY. Radionuclide measurements are used to determine the boundary layer/free tropospheric conditions (Farah et al., 2018). The $\mathrm{CO}_{2}$ surface fluxes are estimated and revealed a clear seasonal cycle, under the influence of plant assimilation, and burning of fossil fuel (Lopez et al., 2015; Ramonet et al., 2020). According to Lopez et al. (2015), the measurements observed at PUY during the night are representative of the central part of France, mostly west of the station. Similarly to other European mountain sites like Schauinsland or Monte Cimone, the daytime values are more influenced by local sources, and therefore they are generally excluded in the large-scale atmospheric inversions (Broquet et al., 2013; Bergamaschi et al., 2018).

Reactive gases concentrations such as ozone have, however, decreased slightly but not significantly over the past 20 years $(-0.1 \pm 1.2$ ppbv per decade, Fig. 8). Expected marked seasonal variations (more $\mathrm{O}_{3}$ in summer due to photochemistry, less in winter) are in line with observations in Europe since 1990 (Gilge et al., 2010; Jonson et al., 2006), while its primary precursors like $\mathrm{NO}_{x}$ have significantly decreased (not shown). This slight decrease in ozone for 20 years is consistent with the ozone trend reported at surface stations within the EMEP network between 1990 and 2012. Changes in long-range transport, a reduced titration by NO due to less $\mathrm{NO}_{x}$ availability, and higher biogenic emissions in a warm- 


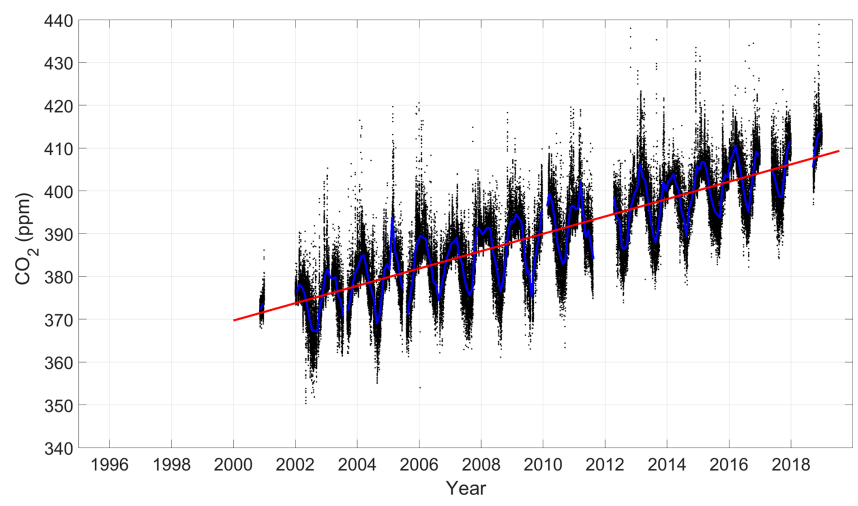

Figure 7. Long series of $\mathrm{CO}_{2}$ at the PUY station (slope: $+20.2 \pm$ $1.7 \mathrm{ppm}$ per decade). The hourly means are in black, the monthly means are in blue, and the linear regression line is in red.

(a)

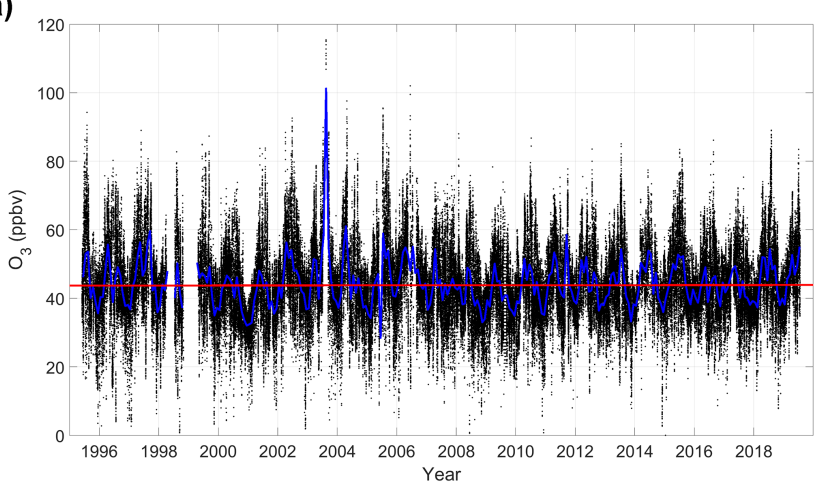

(b)

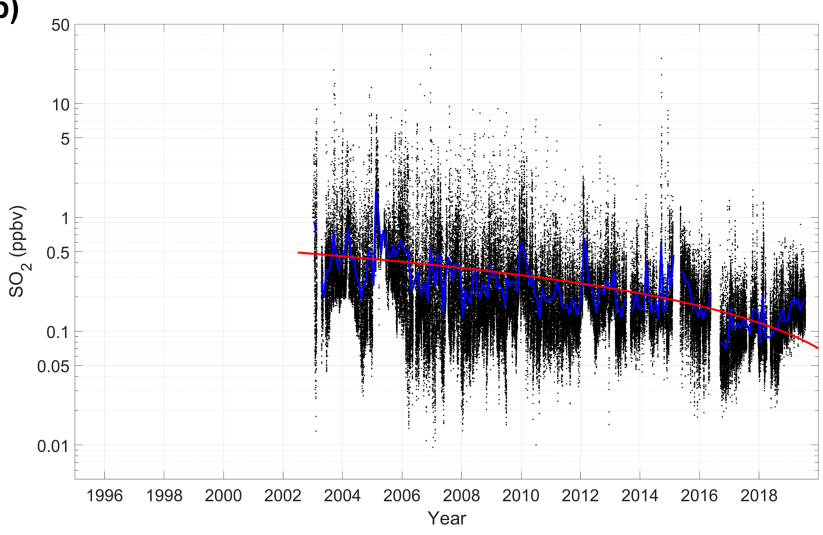

Figure 8. Long series of reactive gases at the PUY station: $\mathrm{O}_{3}$ (a, slope: $-0.1 \pm 1.2 \mathrm{ppbv}$ per decade) and $\mathrm{SO}_{2}$ (b, slope: $-0.23 \pm$ 0.05 ppbv per decade). The $\mathrm{SO}_{2}$ values have been plotted on a logarithmic $y$ axis. The color code is the same as Figs. 4 and 7.

ing climate could explain these trends (Colette et al., 2016). Due to their complexity, the relationships between $\mathrm{O}_{3}$ precursors need further supplementary analyses that are currently underway.

By contrast, sulfur dioxide has dropped significantly in the last 15 years $\left(-0.23 \pm 0.05 \mathrm{ppbv}_{\text {decade }}{ }^{-1}\right)$ due to the reduction of its primary emission. This is consistent with $\mathrm{SO}_{2}$ trends observed over Europe (Hohenpeissenberg, Giannitrapani et al., 2006). The monitoring of NMHCs is too recent for deriving multi-year trends but shows the systematic presence of major anthropogenic and biogenic NMHCs with levels in the same range as the ones reported at European GAW stations like the Monte Cimone and Hohenpeißenberg stations (Wang et al., 2020). Due to the diurnal and seasonal cycles of the boundary layer height, compounds influenced by anthropogenic sources are more concentrated in summer than in winter when PUY is in the free troposphere. Local and regional emissions will influence the trace gas concentrations, especially in summer and daytime.

\subsection{Aerosol}

Studies of microphysical, chemical, and dynamical atmospheric processes are carried out using CO-PDD measurements. They cover the whole life cycle of aerosol particles from their formation by nucleation from gaseous precursors, chemical processing during transport, activation to cloud droplets to washout from precipitation.

The total particle number concentration $(>10 \mathrm{~nm})$ currently measured at PUY is on average $\sim 2 \times 10^{3} \mathrm{~cm}^{-3}$, which corresponds to intermediate values compared to observations reported from neighboring mountain stations in $\mathrm{Eu}-$ rope (Laj et al., 2020), such as for instance Montseny (Spain, $700 \mathrm{~m}$ a.s.l., $\sim 3 \times 10^{3} \mathrm{~cm}^{-3}$ ) or Jungfraujoch (Switzerland, $3578 \mathrm{~m}$ a.s.l, $\sim 2 \times 10^{2} \mathrm{~cm}^{-3}$ ). As illustrated in Fig. 9, the aerosol number concentration tends to overall exhibit a slight decrease over the past 15 years at PUY, on the order of $-9 \pm 5 \times 10^{2} \mathrm{~cm}^{-3}$ per decade. Deeper investigation of this trend is currently being performed and will include a more detailed discussion of these aspects. The variability of atmospheric aerosol number concentration at PUY shows a marked seasonal variation with a maximum during the summer, consistent with observations from other high-altitude sites where a stronger seasonal contrast is usually observed compared to continental lowland sites (Laj et al., 2020). A daily cycle is also very clear, with peak concentrations during the day. These seasonal and daily variations can be explained by a combination of factors, including a fundamental role of the dynamics of the planetary boundary layer and its exchanges with the free troposphere as well as a nonnegligible impact of nucleation (or new particle formation (NPF) events) on the particle size distribution (Venzac et al., 2009). In fact, the dynamics of the planetary boundary layer, in connection with the altitude and the topography of the sites, plays a major role in the transport of both preexisting particles and gaseous precursors at high altitude and in turn significantly contributes to the differences observed among mountain stations (Collaud Coen et al., 2018). During the day, the boundary layer (BL) height increases until it reaches PUY, transporting at altitude the aerosols emitted from the surface. This vertical transport by convective mixing is more marked in summer than in winter. At night, 


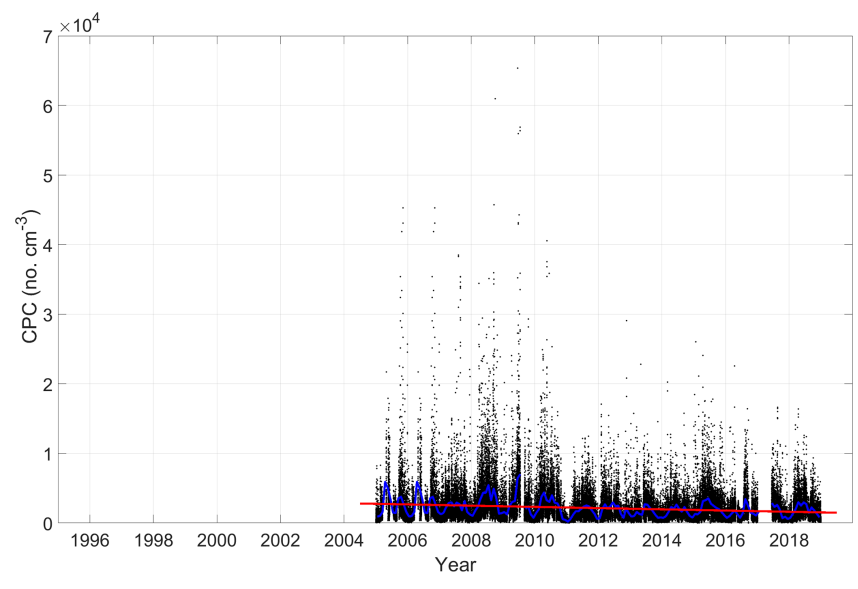

Figure 9. Long series of aerosol particle number at the PUY station (slope: $-9 \pm 5 \times 10^{2} \mathrm{~cm}^{-3}$ per decade). The color code is the same as Figs. 4,7 , and 8.

the concentrations are more representative of the free troposphere (FT)/residual night layer (RL), and the database acquired for several years provides particle size spectra of background air masses. It is clear that the nocturnal residual layer is largely influenced by the diurnal boundary layer, as evidenced by the seasonal variability of the concentrations persisting at night. A more detailed segregation of BL/FT air masses using a set of measurements and model outputs shows that the size distribution actually keeps the air-mass-type signature even in air masses transported in the FT for more than $75 \mathrm{~h}$ (Farah et al., 2018).

The frequency of new particle formation events is on average $30 \%$ of the measurement days (Rose et al., 2013; Venzac et al., 2007), which is a relatively high frequency compared to most European low-troposphere environments (Manninen et al., 2010). A key question is to characterize the vertical extension of these new particle formation events. Size distribution measurements performed simultaneously at PUY and OPME show that for over $45 \%$ of the time, NPF events occur at high altitude but not at low altitude. Such a situation is mostly observed when the planetary boundary layer height derived from lidar measurements performed at Cézeaux indicates that the PUY station is close to or within the lower FT. The remaining observations show that NPF occurs over the entire atmospheric boundary layer (Boulon et al., 2011). This enhanced NPF frequency at high altitude is observed despite the fact that clouds, often found at PUY, are inhibiting the NPF processes as they represent a large condensation surface that acts as a sink for aerosol embryos and condensable gases (Venzac et al., 2007).

Specific measurements in the free troposphere show that the process of forming neutral clusters dominates over the formation of ionized particles (Rose et al., 2015), but overall ion-induced nucleation is promoted at high altitudes compared to low altitudes (Sellegri et al., 2019).
Observations of the aerosol chemical fractions further improved our knowledge of the sources and processes of aerosol transformation in the atmosphere. We find that anthropogenic emissions have a limited impact on PUY measurements, making PUY representative of a rural background site. The organic compounds represent a large fraction of the aerosol mass at aerosol diameters less than $400 \mathrm{~nm}$ observed at PUY (Freney et al., 2011; Sellegri et al., 2003b). The seasonality of aerosol mass is similar to the one found for aerosol number, showing highest mass concentrations measured during the spring and summer months and lowest concentrations during the winter months (Bourcier et al., 2012b). Aerosol chemical composition monitored at PUY is highly variable, but average concentration monitored at PUY over the period April 2015-February 2016 exhibits the following values: organic $57 \%\left(2 \mu \mathrm{g} \mathrm{m}^{-3}\right)$, followed by sulfate $16 \%\left(0.4 \mathrm{\mu g} \mathrm{m}^{-3}\right)$, nitrate $12 \%\left(0.3 \mu \mathrm{g} \mathrm{m}^{-3}\right)$, ammonium $10 \%\left(0.24 \mu \mathrm{g} \mathrm{m}^{-3}\right)$, and BC $5 \%\left(0.13 \mu \mathrm{g} \mathrm{m}^{-3}\right)$ (Farah et al., 2020). In particular, the organic fraction is higher in summer because of additional sources of secondary organic carbon at altitude with respect to the boundary layer in summer. The organic aerosol detected at PUY can be broken down into three fractions of different origins: a dominant fraction of oxygenated semi-volatile compounds representative of aged aerosols and transported over long distances, a fraction of organic compounds from biomass combustion, significant in winter, and a fraction of primary organics which is minor (Freney et al., 2011; Farah et al., 2020).

One of the impacts of aerosol particles on the climate is that it scatters and absorbs solar and telluric radiation. These interactions depend on the concentration, size, and chemical composition of the atmospheric aerosol, but they can be directly measured in terms of scattering and absorption coefficients. A median scattering coefficient of $\sim 10 \mathrm{Mm}^{-1}$, in the range of values observed at other mountain sites, was obtained by Pandolfi et al. (2018) for the period 2007-2014 at PUY. Seasonal medians in the range $0.7-9 \mathrm{Mm}^{-1}$ were in addition more recently reported by Laj et al. (2020) for the year 2017, together with median absorption coefficients of 0.92 and $0.44 \mathrm{Mm}^{-1}$ for spring and fall, respectively. The climatology of these scattering and absorbing properties shows that, quite logically, compared to the results presented previously, the height of the boundary layer strongly influences the optical properties of the aerosol at the puy de Dôme, since it influences the concentrations in number, mass concentrations, and chemical composition. This influence is reflected in clear daily and seasonal variations in optical properties, when considering the whole long-term data set of optical properties. A significant decrease in the daytime aerosol scattering coefficient during summer and winter was in particular observed by Pandolfi et al. (2018) over the period 20072014. The recent results from Collaud Coen et al. (2020) however slightly balance the previous findings of Pandolfi and co-workers, as an overall decrease of $-0.147 \% \mathrm{yr}^{-1}$ over the decade 2009-2018 was observed but reported as not 
statistically significant. A statistically significant decreasing trend was in contrast found for the absorption coefficient over the period 2009-2017, on the order of $-0.017 \% \mathrm{yr}^{-1}$. These observations are in agreement with aerosol mass (PM) decay observed at the European level, in relation to $\mathrm{SO}_{2}$ emission regulations. In situ optical data were also used to evaluate aerosol remote sensing retrievals. In situ measurements of aerosol optical and size properties measured at PUY can be combined with integrated sun-photometer measurements and lidar profiles to assess the accuracy of inversion algorithms for retrieving aerosol size distributions, showing a fairly good agreement between in situ and column-average aerosol size distribution when the structure of the atmosphere is taken into account (Chauvigné et al., 2016).

In order to evaluate both the climate and health impacts of particles in the atmosphere, it is essential to know the quantity of water that the aerosol particles contain at a given relative humidity level (i.e., hygroscopicity). Compared to measurements made at other elevation sites, the hygroscopic properties of the aerosol sampled at PUY are intermediate, between that of the aerosol sampled at higher altitudes in the Alps (Jungfraujoch, $3580 \mathrm{~m}$ a.s.l., Switzerland) (Sjogren et al., 2008) and aerosols sampled at a lower altitude at Great Dun Fell (848 m a.s.1., England) (Svenningsson et al., 1997) or Kleiner Feldberg ( $878 \mathrm{~m}$ a.s.l., Germany) (Svenningsson et al., 1994). Lower-elevation sites contain a larger fraction of hydrophobic aerosols from the lower layers of the atmosphere, and higher-elevation sites or ocean-influenced air masses contain a larger fraction of highly hygroscopic aerosols (sea salts). This is reflected by the observations performed at PUY, where $\sim 45 \%$ of the sampled air masses originate from oceanic regions and tend to contain more hygroscopic particles compared to other sectors (Holmgren et al., 2014).

Regardless of the air-mass type, the moderately hygroscopic particles (hygroscopic growth factor close to 1.4) dominate the entire aerosol number concentration, illustrating the effect of ageing of the aerosol during transport.

Lastly, CCN measurements performed at PUY show that $\mathrm{CCN}$ concentrations are highest in continental air masses compared to oceanic air masses, because these air masses contain higher particle number concentrations and also a higher proportion of inorganic (hence hygroscopic) compounds. The aerosol activation diameter at PUY is generally close to $100 \mathrm{~nm}$ at the supersaturation of $0.24 \%$, and the number concentration of particles larger than $100 \mathrm{~nm}$ is a fairly good approximation of the number of cloud droplets (Asmi et al., 2012). The mixing of the aerosol is however influencing the way each chemical component is entering cloud droplets. It has been shown that the activated fraction of inorganic aerosol particles is 0.76 for $200 \mathrm{~nm}$ particles and 0.93 for $500 \mathrm{~nm}$ particles, while it is only 0.14 for organic species at all sizes of particles (Sellegri et al., 2003a). It was also found that elemental carbon (EC) has a higher activation fraction than organic carbon. These results suggest that inorganic and organic species are externally mixed, while EC has likely experienced internal mixing with inorganic species during the course of transport to the site.

\subsection{Clouds}

In a similar way to that for the atmospheric aerosol, cloud studies, from the mechanisms driving the activation of cloud droplets and the cloud microphysical properties to the incloud chemical and biological processes and their impact on atmospheric chemistry, have been among the main topic studied at the puy de Dôme for several decades. Clouds are frequently observed at the PUY station (Baray et al., 2019), in liquid, supercooled, or mixed-phase conditions. The instrumental deployment, including the wind tunnel, counterflow virtual impactor, and cloud droplet collectors allows us to study the different phases of clouds separately.

Cloud droplets are efficient scavengers of chemicals resulting from the aerosol particles acting as cloud condensation nuclei and also from the dissolution of soluble species transferred from the gas phase. The liquid phase of clouds is a particularly reactive medium, influencing the life cycle of many key atmospheric compounds. Cloud water therefore contains a myriad of primary and secondary chemical compounds of both natural and anthropogenic origins that can react, producing additional secondary products that can return to the gas or aerosol phases upon cloud evaporation.

Cloud chemistry studies at the puy de Dôme started early in 2000 with direct measurements of the scavenging efficiencies of aerosol particles and the main organic and inorganic gases for both liquid and mixed-phase clouds (Lajet al., 2001; Sellegri et al., 2003a, b; Voisin et al., 2000). These works demonstrated that equilibrium predicted by thermodynamics cannot explain the observed concentrations. These specific experiments were completed by

- addressing a long-term variability approach in 2004 and 2014 (Deguillaume et al., 2014; Marinoni et al., 2004),

- the innovative dimension of biological processes (Amato et al., 2005), and

- the recent use of high-resolution mass spectrometry to address the complex organic molecular characterization (Bianco et al., 2018, 2019a).

The PUY station is, indeed, an ideal site to collect cloud samples over long time periods and to characterize them chemically (see Sect. 5.4.1). During their atmospheric transport, air masses arriving at PUY are enriched by chemical compounds emitted by various sources. This leads to a specific signature observed in the cloud water chemical composition. This long-term monitoring of the chemical composition of cloud water allows us to classify clouds into various categories (highly marine, marine, continental, and polluted) that serve to define a chemical scenario for modeling studies (Deguillaume et al., 2014). For this, multivariate statistical 
analyses were performed considering the concentrations of the main inorganic ions and $\mathrm{pH}$; the back-trajectories of the air masses that reach the PUY station for each cloud event were also calculated to confirm the classification (Bianco et al., 2018). This cloud database was recently complemented by measurements of trace metals that help to evaluate the impact of anthropogenic and natural sources on the cloud and to better discriminate the origin of the air masses (Bianco et al., 2017).

In parallel to cloud chemical composition, microorganisms present in clouds (bacteria, fungi) have been studied systematically at PUY since 2003 (Sect. 5.4.1). This longterm observation of cloud biological composition is a unique database. The main sources of microorganisms are associated with continental emissions, more specifically vegetation. A few genera dominate the pool of cultivable microorganisms: for bacteria, for example, Pseudomonas and Sphingomonas (Proteobacteria) are frequently detected. The recurring presence of certain microbial genera reveals that vegetation is one of the major sources, which could also result from the development of strategies of specific aerosolization or properties compatible with their survival in clouds (Joly et al., 2015; Vaitilingom et al., 2012). Microbial concentrations reach values of roughly $10^{4}-10^{5}$ bacteria per milliliter and $10^{3}-10^{4}$ fungi and yeasts per milliliter in cloud water. While working with microorganisms isolated from cloud water, it has been observed that these microorganisms are capable of synthesizing molecules, such as surfactants, that can modify aerosol CCN produce. The presence, abundance, and variability of ice nucleation active biological particles and microorganisms were also studied at the PUY and Opme stations (Joly et al., 2013, 2014; Pouzet et al., 2017). Biological ice nuclei are known to induce freezing at elevated temperature $\left(>-10^{\circ} \mathrm{C}\right)$ (Joly et al., 2013), but their abundance in the atmosphere has been poorly investigated. The number of biological ice nuclei relative to the total number was estimated at $92 \%$ of samples between -6 and $-8^{\circ} \mathrm{C}$ and at $65 \%$ at $-10^{\circ} \mathrm{C}$ (Joly et al., 2014) for cloud water samples collected at PUY in contrasted environmental conditions. Recently, in order to better understand microbial life conditions in clouds and its possible impacts, molecular studies were conducted. An important biodiversity including active microbial groups was depicted by high throughput sequencing (Amato et al., 2017). Their metabolic functioning was explored by metagenomics/metatranscriptomics approaches (Amato et al., 2019). The results demonstrated that microorganisms face oxidants, osmotic shocks, and cold in clouds, which potentially impacts cloud physics and chemistry by acting on the oxidant capacity, iron speciation and availability, and the carbon and nitrogen atmospheric budgets.

The cloud medium allows complex transformations of chemical compounds by both photochemical and biological processes. Respective efficiencies of those transformations working directly on the cloud medium have been intensively studied in this last decade. The oxidative capacity of cloud waters sampled at PUY was investigated during three field campaigns from 2013 to 2014. It was demonstrated that hydroxyl radical $\left(\mathrm{HO}^{\circ}\right)$ production in the aqueous phase is efficient and mainly due to the photolysis of hydrogen peroxide (Bianco et al., 2015). This confirms previous measurements at the PUY station where $\mathrm{H}_{2} \mathrm{O}_{2}$ was monitored (Marinoni et al., 2011). $\mathrm{H}_{2} \mathrm{O}_{2}$ showed diurnal variation, demonstrating its photo-reactivity, and also a dependence on the air-mass origin. Abiotic pathways, such as $\mathrm{HO}^{-}$-mediated mechanisms, compete with biotic degradation. Microorganisms in cloud water are metabolically active and can metabolize organic compounds that are used as nutrients (Bianco et al., 2019b; Vaitilingom et al., 2011, 2013). They are also able to degrade pollutants such as phenols (Lallement et al., 2018b). Moreover, they interact with reactive oxygen species, thus playing another role in cloud chemistry: they destroy oxidants that can potentially damage cells, reducing the concentration of precursors $\left(\mathrm{H}_{2} \mathrm{O}_{2}\right.$ in particular) of reactive oxygen species (Vaïtilingom et al., 2013; Wirgot et al., 2017). However, the endogenous microflora was not shown to impact the steady-state hydroxyl radical concentrations (Lallement et al., 2018a).

All those degradation processes need to be evaluated and compared in the framework of the cloud system. For this a new cloud chemistry model called CLEPS (Cloud Explicit Physico-Chemical Scheme) was recently developed (Mouchel-Vallon et al., 2017), allowing the description of the oxidation of inorganic and organic compounds in the gas and aqueous phases as well as the mass transfer between these two phases. This model was recently evaluated with regards to the long-term observations of the aqueous-phase composition of the clouds sampled at PUY (Rose et al., 2018).

\subsection{Water vapor and rain}

The water is naturally present in the atmosphere in all three physical states: gas (water vapor) in the atmosphere, solid ice and snow, and liquid water (liquid clouds and rainfall). The atmospheric water vapor has a complex life cycle, which includes vertical and horizontal transport, mixing, condensation, precipitation, and evapotranspiration. The understanding of cloud processes and precipitation from the local to synoptic scales involves a finely described multi-scale interaction between water vapor, cloud hydrometeors and precipitation, and their dynamics and radiative properties.

The GPS technology combined with meteorological measurements allows us to continuously measure the integrated water vapor content in the atmosphere with a high temporal resolution. Having stations at different altitudes but within a limited spatial range to document the vertical variability of atmospheric water vapor has shown that the urban layer (i.e., the layer between the two different altitude sites Opme and Cézeaux) exhibits somewhat constant water vapor content, and the major water vapor variations occur in the upper troposphere level, in particular in the presence of west- 
erly flows that bring elevated water vapor content over the mountain ridge (Van Baelen and Penide, 2009). GPS stations have been installed in Opme, PUY, and Cézeaux and are currently operating, allowing studies on the relationship between water vapor and rainfall (Labbouz et al., 2013). A recent study based on 5 years of measurements of integrated water vapor content by GPS, mixing ratio of water vapor at the surface by humidity sensors, and rainfall rate by rain gauges and disdrometers showed a statistical link between these various parameters, and more precisely that in $76 \%$ of the cases, a peak of water vapor precedes that of rain by $20 \mathrm{~min}$. The wetter the atmosphere, the more the precipitations and the temporal delay are important (Labbouz et al., 2015). An analysis of decadal in situ and remote sensing observations of water vapor based on the measurements at CO-PDD make it possible to document the variability, cycles, and trends of surface and tropospheric water vapor at different timescales and the geophysical processes responsible for the water vapor distributions (Hadad et al., 2018), showing that the annual cycle of water vapor is clearly established for the two sites of different altitudes and for all types of measurements. Cézeaux and PUY present almost no diurnal cycle, suggesting that the variability of surface water vapor at this site is more influenced by a sporadic meteorological system than by regular diurnal variations. The vertical dimension given by the lidar and GPS measurements showed that the lidar climatological profiles of water vapor present the same annual cycle but a larger variability than satellite profiles (COSMIC-FORMOSAT and AQUA-AIRS). The Xband radars have been extensively used in international campaigns such as COPS and HYMEX to study the interaction of convective rain with water vapor, in conjunction with GPS observations (Labbouz et al., 2013; Planche et al., 2013; Van Baelen et al., 2011), or orography, in conjunction with MRRs (Zwiebel et al., 2016). The local synergy of simultaneous Xband radar and rain gauge measurements based on innovative geostatistical methods has also been used to improve the fine mapping of rainfall (Seck and Van Baelen, 2018). This geostatistical technique allowed, for example, an improvement of $54 \%$ in terms of bias reduction for kriging.

Finally, the concentration of ice-nucleating particles in precipitation has been measured in rain samples at Opme during a more than a 1-year period, showing variability over 2 orders of magnitude at a given temperature. The data support a natural link with the hydrological cycle as well as a strong impact of human activities on the role of INP as triggers of precipitation (Pouzet et al., 2017).

\subsection{Dynamics and long-range transport of radionuclides}

In the context of a changing climate, it is of primary importance to be able to detect and quantify changes in GHGs, but also to connect these changes to the different atmospheric compartments in order to identify the dynamical links and the strength of their exchanges. Jet streams are strong zonal winds in the upper troposphere which play an important role in the dynamical coupling between the stratosphere and troposphere and which are also likely to induce long-range transport of large quantities of atmospheric constituents (gas and aerosol). The analysis of the 15 years of data of the Opme VHF profiler (1999-2014) compared with a similar series at Lannemezan (southern France) established the climatological behavior of tropospheric wind, which reveals dominant westerly high tropospheric winds with a maximum speed in winter of $22 \mathrm{~m} \mathrm{~s}^{-1}$ at the altitude $9 \mathrm{~km}$ (Baray et al., 2017). This predominance of the westerly direction is due to upper tropospheric jet streams, strong winds at upper tropospheric altitudes which, in the most intense cases, exceed $50 \mathrm{~m} \mathrm{~s}^{-1}$, able to be at the origin of stratosphere-troposphere exchanges. The jet stream shows a clear seasonality, with a predominance in winter (3\% to $10 \%$ of hourly profiles) and a minimum in summer (less than $1 \%$ ), and a decadal trend $(+1.6 \pm 1.2 \%$ per decade). These results are corroborated by the analysis of radionuclides (beryllium-sodium report) and the analysis of the Lannemezan upper tropospheric wind data series.

The presence of radionuclides in aerosol and rain has also been investigated (Bourcier et al., 2012a). Measurements were conducted at three sampling sites located at different altitudes during 2 years, in both the rain and aerosol phases. The rain was sampled at Opme (boundary layer site), while the aerosol particles were collected at two different altitudes (Cézeaux and PUY), which allow a better characterization of the vertical atmospheric column being washed out. Various chemical analyses were performed during specific campaigns to characterize reactive $\left(\mathrm{NO}_{3}^{-}, \mathrm{SO}_{4}^{2-}, \mathrm{NH}_{4}^{+}\right.$, and $\mathrm{K}^{+}$) and inert $\left({ }^{7} \mathrm{Be},{ }^{210} \mathrm{~Pb}\right.$, and $\left.{ }^{137} \mathrm{Cs}\right)$ species transfer from the aerosol to the rain phase. Using the classical washout ratio calculated with the aerosol concentration sampled at the same altitude as the rain collectors, we observed a seasonality of the washout ratio for radionuclides, with a higher value in winter and a lower value in summer. At PUY, local contamination does not influence the aerosol concentration.

Long-distance transport events of atmospheric constituents can be observed by instruments operating at the COPDD site. For example, cesium isotopes $\left({ }^{134} \mathrm{Cs}\right.$ and $\left.{ }^{137} \mathrm{Cs}\right)$ are directly related to nuclear accidents, and their concentration in the cloud and rainy waters of PUY and Opme, respectively, increased by a factor of 40 during the Fukushima accident in March 2011 (Masson et al., 2015). Over the following weeks, concentrations decreased more slowly in cloud water than in rainwater and more slowly in rainwater than in aerosol sampling. ${ }^{134} \mathrm{Cs}$ was detected in the aerosol phase, in the rainwater and in the cloud water for 3, 11, and 18 months, respectively, after the accident. Recent European-scale detection events of anthropogenic radionuclides $\left({ }^{131} \mathrm{I},{ }^{75} \mathrm{Se}\right.$, ${ }^{106} \mathrm{Ru}$ ) were observed in France thanks to the radionuclide monitoring performed in Opme and at PUY (Masson et al., 2015). Besides accident situations, routine comparison of the 
${ }^{137} \mathrm{Cs}$ results at the summit and in Opme makes it possible to highlight the presence of sporadic high-altitude Saharan dust intrusions.

\section{Conclusions and future plans}

The puy de Dôme is a century-old meteorological observation site, and CO-PDD in its present configuration has now more than 20 years of microphysical, chemical, and remote sensing measurements. CO-PDD is dedicated to the longterm atmospheric survey in the context of climate change and offers a unique instrumentation and data set to document the complex connections linking precipitation and radiation, but also gas and particle cloud interactions. This allows COPDD to play an active role in European infrastructures such as ACTRIS or ICOS. Recent instrument acquisitions funded through regional, national, and European projects continue to strengthen the observation and research capacity of CO-PDD and will allow us in the future to

- continue to respond to the scientific air quality and climate change key questions and to provide data available for the scientific community, and

- develop new research activities, especially for linking the different atmospheric compartments.

For example, the multiphasic organic composition (MOCCA) instrument (PTR-ToF-MS by Ionicon) currently under development will help us to understand the evolution of atmospheric particles as they are formed from different gas-phase precursors and react and grow in the atmosphere, prior to being scavenged by cloud. This new platform will be operational at the puy de Dôme station in 2020 to document the gas-aerosol-cloud organic speciation. This MOCCA instrument is composed of a PTR-ToF-MS $6000 \mathrm{X} 2$ (Ionicon) coupled with a fast GC to directly sample and analyze the volatile organic compounds (VOCs) (including biogenic VOCs and oxygenated VOCs), with an aerosol inlet (CHARON), a particle inlet to directly sample and analyze the chemical composition of atmospheric sub- $\mu \mathrm{m}$ particulate organic matter. A separate head-space sampler is fitted to analyze cloud water samples.

The synergy of cloud and MRR radars will allow the monitoring of the cloud life cycle and corresponding rain structure as well as the observation of the cloud-to-rain transition with a high spatial and temporal resolution. Two hydrometeor radar instruments will be in operation in 2020 or 2021 for the study of clouds and precipitation: a pulsed cloud radar at $35 \mathrm{Ghz}$ and a vertical meteorological radar profiler at $24 \mathrm{Ghz}$ to obtain the Doppler spectra of hydrometeors between $15 \mathrm{~m}$ and $6 \mathrm{~km}$. These instruments will first be deployed at a site near the Aydat Lake area $(12 \mathrm{~km}$ south of PUY) to study the microphysical and thermodynamical characteristics of precipitating clouds in relation to the biological and physico-chemical composition of cloud water and to link these properties with the subsequent impact on terrestrial and aquatic ecosystems. Afterwards, these instruments will operate on a routine basis at the Opme or Cézeaux site and integrate in the framework of CO-PDD.

Finally, the characterization of bioaerosols which are potentially important to organic aerosols in the atmosphere, and play an active role as both cloud condensation nuclei and ice nuclei, providing us with a new means to understand their sources and links with the cloud system (such as CCN for example). Biological aerosol particles are also important in the context of air quality studies and health effect research. Recently, a bioaerosol counter (WIBS-NEO, DMT, USA) was acquired. This fluorescent aerosol particle size spectrometer was built for real-time detection of bioaerosols. This instrument will provide detailed information (detailed size, asymmetry factor) on atmospheric bacteria, molds, pollen, and other bioaerosols. Three UV wavebands have been selected to optimize detection of common bioaerosols (tryptophan and NADH). It has been installed at the PUY station since October 2018, and data analysis is ongoing.

These new instruments will enable CO-PDD to be an important element of the French and European atmospheric research landscapes in order to

- respond to current scientific issues on process characterization and long-term monitoring,

- maintain and develop the potentialities for hosting external teams (transnational access),

- continue to export instrumental expertise on other sites (e.g., in situ measurements of the Maïdo station, Indian Ocean, southern subtropics), and

- constitute an efficient tool for early detection of atmospheric hazards (e.g., pollution peaks, volcanic eruptions, forest fires, nuclear accidents). 
Appendix A: List of acronyms

\begin{tabular}{|c|c|}
\hline ACSM & Aerosol Chemical Speciation Monitor \\
\hline ACTRIS & Aerosol Cloud and Trace gases Research Infrastructure \\
\hline AERONET & Aerosol Robotic Network \\
\hline AIS & Air Ion Spectrometer \\
\hline AQUA-AIRS & Atmospheric Infrared Sounder \\
\hline $\mathrm{BC}$ & Black carbon \\
\hline BIOCAP & Impact biologiques et photochimiques sur la capacité oxydante du nuage \\
\hline $\mathrm{CCNc}$ & Cloud condensation nuclei chamber \\
\hline CHAIN & Characterisation of atmospheric ice nuclei \\
\hline CLAP & CLimate Relevant Aerosol Properties \\
\hline CLEPS & Cloud Explicit Physico Chemical Scheme \\
\hline CNRS & Centre National de la Recherche Scientifique \\
\hline CO-PDD & Cézeaux-Aulnat-Opme-Puy De Dôme \\
\hline COSMIC-FORMOSAT & Constellation Observing System for Meteorology, Ionospheric, and Climate \\
\hline $\mathrm{CPC}$ & Condensation particle counter \\
\hline CRDS & Cavity ring-down spectroscopy \\
\hline DMA & Differential mobility analyzer \\
\hline EARLINET & European Aerosol Research Lidar Network \\
\hline ECMWF & European Centre for Medium-Range Weather Forecasts \\
\hline ENSTA & École nationale supérieure de techniques avancées (Brest) \\
\hline EUSAR & European Supersites for Atmos. Res. \\
\hline GAW & Global Atmosphere Watch \\
\hline GC-FID & Gas Chromatography - Flame Ionization Detector \\
\hline GCMS & Gas chromatography mass spectrometry \\
\hline GHG & Greenhouse gas \\
\hline GLONASS & GLObal NAvigation Satellite System \\
\hline GPS & Global Positioning System \\
\hline HTDMA & Hygroscopic Tandem Differential Mobility Analyser \\
\hline HYMEX & HYdrological cycle in Mediterranean EXperiment \\
\hline ICOS & Integrated Carbo Observation System \\
\hline INSU & Institut National des Sciences de l'Univers \\
\hline IRSN & Institut de Radioprotection et de Sûreté Nucléaire \\
\hline JMA & Japan Meteorological Agency \\
\hline KNMI & Royal Netherlands Meteorological Institute \\
\hline LA & Laboratoire d'Aérologie (Toulouse) \\
\hline LaMP & Laboratoire de Météorologie Physique (Clermont-Ferrand) \\
\hline Lidar & Light detection and ranging \\
\hline LSCE & Laboratoire des Sciences du Climat et de l'Environnement (Paris) \\
\hline MAAP & Multiangle Absorption Photometer \\
\hline MOCCA & Mass spectrOmetry for the multiphasic Composition of the Cloudy Atmosphere \\
\hline MRR & Micro Rain Radar \\
\hline NAIS & Neutral cluster and Air Ion Spectrometer \\
\hline NASA & National Aeronautics and Space Administration \\
\hline NOAA & National Oceanic and Atmospheric Administration \\
\hline NTP & Normal Temperature and Pressure \\
\hline $\mathrm{OPC}$ & Optical Particle Counter \\
\hline OPERA & Permanent observatory of the radioactivity \\
\hline OSU & Observatoire des Sciences de l'Univers \\
\hline OPGC & Observatoire de Physique du Globe de Clermont Ferrand \\
\hline PSM & Particle Size Magnifier \\
\hline PTR-TOF-MS & Proton Transfer. Reaction - Time of Flight - Mass Spectrometer \\
\hline
\end{tabular}


PVM Particle Volume Monitor

Radar Radio detection and ranging

RAMCES Réseau Atmosphérique de Mesure des Composés à Effet de Serre

RENAG REseau NAtional GNSS permanent

SMPS Scanning Mobility Particle Sizer

TEOM-FDMS Tapered Element Oscillating Microbalance-Filter Dynamic Measurement System

UHF Ultra high frequency

VHF Very high frequency

WAI Whole Air Inlet

WIBS-NEO Wideband Integrated Bioaerosol Sensor 


\section{Appendix B: Encountered air masses}

The puy de Dôme is the first mountain chain forming an orographic barrier to the prevailing westerly winds. Long-term monitoring of the chemical composition of clouds performed between 2001 and 2011, coupled with a back-trajectory analysis, has shown that, under cloudy situation, air masses reaching PUY mainly come from the western and northwestern sectors and are classified as "marine" or "highly marine types" (Deguillaume et al., 2014).

In order to provide a more detailed description of encountered air masses arriving on the PUY site, including all weather conditions, we performed a statistical analysis of back-trajectories with the CAT model. CAT (Computing Atmospheric Trajectory Tool) is a recent evolution of the LACYTRAJ model (Clain et al., 2010). LACYTRAJ was a 3-D kinematic trajectory code using initialization wind fields from the ECMWF ERA-Interim Reanalysis with a horizontal resolution of $1^{\circ}$ in latitude and longitude, and 37 vertical levels. A cluster of starting back-trajectory points was defined by the user and advected by the model using a bilinear interpolation for horizontal wind fields and time and a log-linear interpolation for vertical wind field, with a time resolution of 15 min between two trajectory points. The improvements from LACYTRAJ to CAT are the following.

- The initialization with wind fields from the recent ERA5 ECMWF reanalysis of any temporal and spatial resolution. The adaptation to assimilate wind fields on a smaller scale from WRF and MESO-NH mesoscale models is currently under development.

- The integration of topography at a resolution of around $10 \mathrm{~km}$ (Bezdek and Sebera, 2013).

- The possibility of automatically calculating forward and backward trajectories starting at any time, and not only on the hours of the ERA-Interim matrices (00:00, 06:00, 12:00, 18:00 UT), and with variable temporal resolution and starting pressure level (by example measured at an altitude station).

A statistical analysis of back-trajectories was then made using the CAT model for the years 2015 and 2016. Twice a day, a set of trajectories was calculated over a period of $24 \mathrm{~h}$ from an area of $10 \mathrm{~km}$ around the puy de Dôme, and starting from the pressure level measured at the top of the PUY station. Figure B1 shows the total number of path points per $0.5^{\circ}$ square and Table B1 provides the percentage of backtrajectory points by sector (for the full year, and by season).

We observe that the air masses arriving at PUY come mainly from the Atlantic Ocean. These westerly origins are mainly observed in winter (more than $50 \%$ ), but they also occurs during the other seasons (more than $40 \%$ ). $15 \%$ to $24 \%$ of air masses come from potentially polluted areas (easterly), with the larger values in spring $(24 \%)$.
Table B1. Percentage of back-trajectory points in each sector, for the 2015-2016 period, whole year and per season. The category "Near" contains back-trajectory points in a $20 \mathrm{~km}$ radius circle around the PUY station.

\begin{tabular}{lrrrrr}
\hline Sector & $\begin{array}{r}2015- \\
2016\end{array}$ & $\begin{array}{r}\text { Winter: } \\
\text { DJF }\end{array}$ & $\begin{array}{r}\text { Spring: } \\
\text { MAM }\end{array}$ & $\begin{array}{r}\text { Summer: } \\
\text { JJA }\end{array}$ & $\begin{array}{r}\text { Fall: } \\
\text { SON }\end{array}$ \\
\hline Near & 4.7 & 3.9 & 3.9 & 6.0 & 4.6 \\
SSW & 7.3 & 8.8 & 5.9 & 6.5 & 7.3 \\
SWW & 22.9 & 28.1 & 17.5 & 23.9 & 24.8 \\
NWW & 23.4 & 27.2 & 23.1 & 24.4 & 23.5 \\
NNW & 10.4 & 6.7 & 11.0 & 12.6 & 10.3 \\
NNE & 8.4 & 6.1 & 11.5 & 7.8 & 7.5 \\
NEE & 10.7 & 10.5 & 12.5 & 8.1 & 9.8 \\
SEE & 4.8 & 3.0 & 6.0 & 4.1 & 5.0 \\
SSE & 7.4 & 5.7 & 8.6 & 6.6 & 7.2 \\
\hline
\end{tabular}

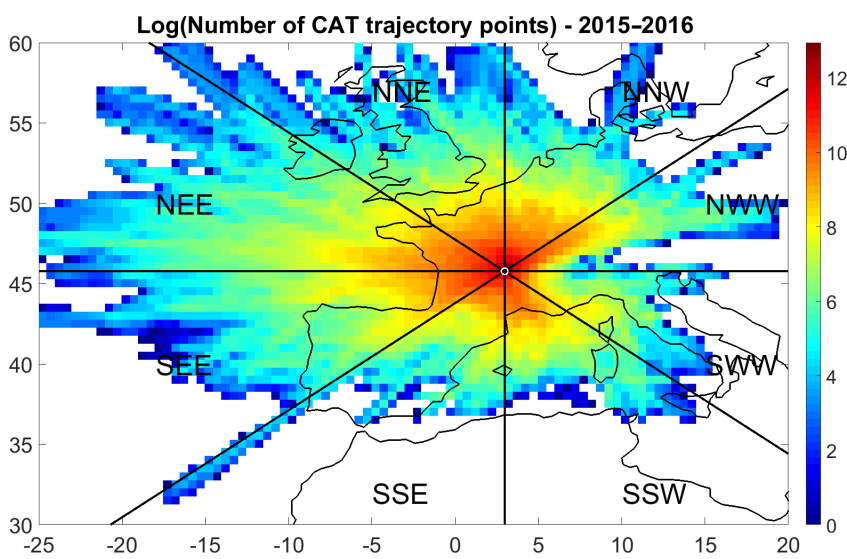

Figure B1. Natural logarithm of the number of CAT back-trajectory points arriving at the summit of the PUY station for the 2015-2016 whole period per scare of $0.5^{\circ}$ size. The white circle has a radius of $20 \mathrm{~km}$ and illustrates the category "Near" of Table B1, and the black lines separate the different sectors. The total number of backtrajectory points is $6.3 \times 10^{6}$ and the largest number of points in a $0.5^{\circ}$ square are $4.2 \times 10^{5}$

It may happen that desert dust aerosol particles are transported over long distance and are observed by the CO-PDD instrumental devices (mainly in winter), but with a transport time larger than $24 \mathrm{~h}$.

Finally, we observe that the category "near" is larger in summer. This may be due to the fact that the site is more frequently in boundary layer condition in summer, with therefore a higher local impact. An analysis using mesoscale model is necessary to investigate this point. 
Data availability. All data produced by CO-PDD are effectively accessible free of charge to a wide user community. Because CO-PDD is part of different national and international initiatives, including the European Research Infrastructures ACTRIS and ICOS, with specific data policies, or the international networks AERONET, not all CO-PDD information can be retrieved by a single data hub, but is split between local, national, and international data centers. Since 2020, a strong effort has been made to apply FAIR (findable, accessible, interoperable, and reusable) principles to some data produced at CO-PDD through the work done within the ENVRI-FAIR (H2020, 2020-2024) EU project that will facilitate uptake of data from different sources.

All data produced at CO-PDD are first stored on local servers including raw data. For optimizing their visibility and local use, some quicklooks, descriptions of measurement systems and near realtime data are accessible through the current OPGC internet portal (OPGC, 2020a). A new website with a virtual observatory (OPGC, 2020b) allowing easier information on data is currently being developed.

A second layer of dissemination is the national level. CO-PDD provides all data produced within national and international initiatives to the national Earth Science Data System and its specific atmospheric component AERIS (AERIS, 2020a). AERIS centralizes all information besides the GPS water vapor column measurements measured at PUY, Cézeaux and Opme which are accessible through the RESIF-RENAG databases (RENAG, 2020; IGN, 2020) and besides the radionucleides measurements available through the OPERA data base (IRSN, 2020) upon request. In addition, some additional information of reactive gases can be accessed at the PAES portal (OMP, 2020).

Finally, the third layer of dissemination is the international level. Data are preserved for long-term archiving by the corresponding Research Infrastructures or networks as part of the archival process and in order to ensure good data management. Each step of the data life cycle is documented in Research Infrastructures Data Management Plans, including collection, curation, data production, preservation, publishing and use of data. More specifically,

- ACTRIS-related information is contained in ACTRIS-DC, including in situ ground-based measurements of aerosol properties and reactive gases (EBAS, NILU, 2020), the aerosol profiling (EARLINET, 2020, including the EARLINET SCC (Single Calculus Chain) for additional lidar products). GAWand EMEP-related information is also accessible through the EBAS data center.

- AERONET-related information from sun-photometer measurements is available through the NASA Goddard Space Flight Center (NASA/GSFC, 2020).

- ICOS-related information is accessible through the ICOS Carbon Portal (ICOS, 2020).

- The E-Profile database contains the Opme and Aulnat wind profiler measurements (EUMETNET, 2020).

Author contributions. JLB, LD and AC have written the manuscript, with contributions of many co-authors. JVB, NC, $\mathrm{AF}$, and $\mathrm{NH}$ are current or past heads of the laboratory (LaMP) or observatory (OPGC). The following co-authors are or have been responsible or in charge of CO-PDD instruments or data. Reactive gases: AgB, LB, AC, LD, JMP, MR, MR and StS. Greenhouse gases: MD, VK, ML, MR, MS, ET and CYK. In situ aerosol: LB, YB, AC, AF, EF, PL, AM, DP, JMP, MR, CR, KS and PV. Cloud measurements: PA, AnB, AgB, MB, TC, NC, AC, LD, AMD, RD, MJ, GM, MP, MS, MV and MW. Radionuclides measurements: LB and OM. Lidar: JLB, PF, MH, and NM. Wind profilers radar, rain gauges/radar and GPS: JLB, SB, CH, FP, YP and JVB. Wind tunnel: GF and CG. Database and data processing: SB, PC, JMP and YP.

Competing interests. The authors declare that they have no conflict of interest.

Acknowledgements. We thank all the people who contributed to the functioning and development of the instrumented site CO-PDD without being a co-author of this article.

Financial support. CO-PDD is an instrumented site of the OPGC observatory and LaMP laboratory, supported by the Université Clermont Auvergne (UCA), by the Centre National de la Recherche Scientifique (CNRS-INSU), and by the Centre National d'Etudes Spatiales (CNES). In addition, some instruments and operations have been founded by the Institut de Radioprotection et de Sûreté Nucléaire (IRSN) and the Commissariat à l'Energie Atomique et aux énergies alternatives (CEA), Région Auvergne and AuvergneRhône-Alpes, Conseil Départemental 63, Clermont Métropole. The research activities have received funding from the European Union's Horizon 2020 research and innovation programme (ACTRIS2 (grant no. 654109)). The authors are also very grateful for the financial support from the Fédération des Recherches en Environnement through the CPER funded by Region Auvergne - RhôneAlpes, the French ministry, ACTRIS Research Infrastructure, and FEDER European Regional funds. Some research projects funded by the French national research agency (ANR) also contributed to the data production of CO-PDD (fund nos. CHAIN ANR-14-CE010003 and BIOCAP ANR-13-BS06-0004).

Review statement. This paper was edited by Johannes Schneider and reviewed by Matthias Beekmann and one anonymous referee.

\section{References}

ACTRIS: European Center for Aerosol Calibration website, available at: https://www.actris-ecac.eu/, last access: 10 June 2020.

AERIS: https://www.aeris-data.fr/, last access: 10 June 2020a.

AERIS: The MAGIC initiative, available at: https://magic. aeris-data.fr/, last access: 10 June 2020b.

Amato, P., Ménager, M., Sancelme, M., Laj, P., Mailhot, G., and Delort, A.-M.: Microbial population in cloud water at the Puy de Dôme: Implications for the chemistry of clouds, Atmos. Environ., 39, 4143-4153, https://doi.org/10.1016/j.atmosenv.2005.04.002, 2005. 
Amato, P., Parazols, M., Sancelme, M., Mailhot, G., Laj, P., and Delort, A.-M.: An important oceanic source of micro-organisms for cloud water at the Puy de Dôme (France), Atmos. Environ., 41, 8253-8263, https://doi.org/10.1016/j.atmosenv.2007.06.022, 2007a.

Amato, P., Parazols, M., Sancelme, M., Laj, P., Mailhot, G., and Delort, A.-M.: Microorganisms isolated from the water phase of tropospheric clouds at the Puy de Dôme: major groups and growth abilities at low temperatures, FEMS Microbiol. Ecol., 59, 242254, https://doi.org/10.1111/j.1574-6941.2006.00199.x, 2007b.

Amato, P., Joly, M., Besaury, L., Oudart, A., Taib, N., Moné, A. I., Deguillaume, L., Delort, A.-M., and Debroas, D.: Active microorganisms thrive among extremely diverse communities in cloud water, PLOS One, 12, e0182869, https://doi.org/10.1371/journal.pone.0182869, 2017.

Amato, P., Besaury, L., Joly, M., Penaud, B., Deguillaume, L., and Delort, A.-M.: Metatranscriptomic exploration of microbial functioning in clouds, Sci. Rep., 9, 4383, https://doi.org/10.1038/s41598-019-41032-4, 2019.

Anonymous: The Puy-De-Dôme Observatory, Nature, 14, 509-511, https://doi.org/10.1038/014509a0, 1876.

Asmi, E., Freney, E., Hervo, M., Picard, D., Rose, C., Colomb, A., and Sellegri, K.: Aerosol cloud activation in summer and winter at puy-de-Dôme high altitude site in France, Atmos. Chem. Phys., 12, 11589-11607, https://doi.org/10.5194/acp-12-115892012, 2012.

Atlas, D., Srivastava, R. C., and Sekhon, R. S.: Doppler radar characteristics of precipitation at vertical incidence, Rev. Geophys., 11, 1-35, https://doi.org/10.1029/RG011i001p00001, 1973.

AXIS: Manufacturer's website, available at: https://www.axis.com/ en, last access: 10 June 2020.

Baray, J.-L., Pointin, Y., Van Baelen, J., Lothon, M., Campistron, B., Cammas, J.-P., Masson, O., Colomb, A., Hervier, C., Bezombes, Y., Banson, S., Duroure, C., Hadad, D., and Tridon, F.: Case Study and Climatological Analysis of UpperTropospheric Jet Stream and Stratosphere-Troposphere Exchanges Using VHF Profilers and Radionuclide Measurements in France, J. Appl. Meteorol. Climatol., 56, 3081-3097, https://doi.org/10.1175/JAMC-D-16-0353.1, 2017.

Baray, J.-L., Bah, A., Cacault, P., Sellegri, K., Pichon, J.-M., Deguillaume, L., Montoux, N., Noel, V., Sèze, G., Gabarrot, F., Payen, G., and Duflot, V.: Cloud occurrence frequency at puy de Dôme (France) deduced from an automatic camera image analysis: Method, validation and comparisons with larger scale parameters, Atmosphere, 10, 808, https://doi.org/10.3390/atmos10120808, 2019.

Bergamaschi, P., Karstens, U., Manning, A. J., Saunois, M., Tsuruta, A., Berchet, A., Vermeulen, A. T., Arnold, T., JanssensMaenhout, G., Hammer, S., Levin, I., Schmidt, M., Ramonet, M., Lopez, M., Lavric, J., Aalto, T., Chen, H., Feist, D. G., Gerbig, C., Haszpra, L., Hermansen, O., Manca, G., Moncrieff, J., Meinhardt, F., Necki, J., Galkowski, M., O’Doherty, S., Paramonova, N., Scheeren, H. A., Steinbacher, M., and Dlugokencky, E.: Inverse modelling of European $\mathrm{CH}_{4}$ emissions during 2006-2012 using different inverse models and reassessed atmospheric observations, Atmos. Chem. Phys., 18, 901-920, https://doi.org/10.5194/acp-18-901-2018, 2018.

Bevis, M., Businger, S., Herring, T. A., Rocken, C., Anthes, R. A., and Ware, R. H.: GPS meteorology: Remote sensing of atmospheric water vapor using the global positioning system, J. Geophys. Res.-Atmos., 97, 15787-15801, https://doi.org/10.1029/92JD01517, 1992.

Bezděk, A. and Sebera, J.: MATLAB script for 3D visualizing geodata on a rotating globe, Comput. Geosci., 56, 127-130, https://doi.org/10.1016/j.cageo.2013.03.007, 2013.

Bianco, A., Passananti, M., Perroux, H., Voyard, G., MouchelVallon, C., Chaumerliac, N., Mailhot, G., Deguillaume, L., and Brigante, M.: A better understanding of hydroxyl radical photochemical sources in cloud waters collected at the puy de Dôme station - experimental versus modelled formation rates, Atmos. Chem. Phys., 15, 9191-9202, https://doi.org/10.5194/acp15-9191-2015, 2015.

Bianco, A., Voyard, G., Deguillaume, L., Mailhot, G., and Brigante, M.: Improving the characterization of dissolved organic carbon in cloud water: Amino acids and their impact on the oxidant capacity, Sci. Rep., 6, 37420, https://doi.org/10.1038/srep37420, 2016.

Bianco, A., Vaïtilingom, M., Bridoux, M., Chaumerliac, N., Pichon, J.-M., Piro, J. L., and Deguillaume, L.: Trace Metals in Cloud Water Sampled at the Puy De Dôme Station, Atmosphere, 8, 225, https://doi.org/10.3390/atmos8110225, 2017.

Bianco, A., Deguillaume, L., Vaïtilingom, M., Nicol, E., Baray, J.-L., Chaumerliac, N., and Bridoux, M.: Molecular Characterization of Cloud Water Samples Collected at the Puy de Dôme (France) by Fourier Transform Ion Cyclotron Resonance Mass Spectrometry, Environ. Sci. Technol., 52, 10275-10285, https://doi.org/10.1021/acs.est.8b01964, 2018.

Bianco, A., Riva, M., Baray, J.-L., Ribeiro, M., Chaumerliac, N., George, C., Bridoux, M. C., and Deguillaume, L.: Chemical characterization of cloud water collected at puy de Dôme by FT-ICR MS reveals the presence of SOA components, ACS Earth Space Chem., 3, 2076-2087, https://doi.org/10.1021/acsearthspacechem.9b00153, 2019a.

Bianco, A., Deguillaume, L., Chaumerliac, N., Vaïtilingom, M., Wang, M., Delort, A.-M., and Bridoux, M. C.: Effect of endogenous microbiota on the molecular composition of cloud water: a study by Fourier-transform ion cyclotron resonance mass spectrometry (FT-ICR MS), Sci. Rep., 9, 7663 https://doi.org/10.1038/s41598-019-44149-8, 2019b.

Boulon, J., Sellegri, K., Hervo, M., Picard, D., Pichon, J.-M., Fréville, P., and Laj, P.: Investigation of nucleation events vertical extent: a long term study at two different altitude sites, Atmos. Chem. Phys., 11, 5625-5639, https://doi.org/10.5194/acp11-5625-2011, 2011.

Bourcier, L., Masson, O., Laj, P., Chausse, P., Pichon, J. M., Paulat, P., Bertrand, G., and Sellegri, K.: A new method for assessing the aerosol to rain chemical composition relationships, Atmos. Res., 118, 295-303, https://doi.org/10.1016/j.atmosres.2012.07.020, $2012 \mathrm{a}$.

Bourcier, L., Sellegri, K., Chausse, P., Pichon, J. M., and Laj, P.: Seasonal variation of water-soluble inorganic components in aerosol size-segregated at the puy de Dôme station (1465 m a.s.1.), France, J. Atmos. Chem., 69, 47-66, https://doi.org/10.1007/s10874-012-9229-2, 2012 b.

Brantner, B., Fierlinger, H., Puxbaum, H., and Berner, A.: Cloudwater chemistry in the subcooled droplet regime at Mount Sonnblick (3106 m a.s.l., Salzburg, Austria), Water Air Soil Poll., 74, 363-384, 1994. 
Broquet, G., Chevallier, F., Bréon, F.-M., Kadygrov, N., Alemanno, M., Apadula, F., Hammer, S., Haszpra, L., Meinhardt, F., Morguí, J. A., Necki, J., Piacentino, S., Ramonet, M., Schmidt, M., Thompson, R. L., Vermeulen, A. T., Yver, C., and Ciais, P.: Regional inversion of $\mathrm{CO}_{2}$ ecosystem fluxes from atmospheric measurements: reliability of the uncertainty estimates, Atmos. Chem. Phys., 13, 9039-9056, https://doi.org/10.5194/acp-139039-2013, 2013.

Cavalli, F., Viana, M., Yttri, K. E., Genberg, J., and Putaud, J.-P.: Toward a standardised thermal-optical protocol for measuring atmospheric organic and elemental carbon: the EUSAAR protocol, Atmos. Meas. Tech., 3, 79-89, https://doi.org/10.5194/amt-3-792010, 2010.

Chauvigné, A., Sellegri, K., Hervo, M., Montoux, N., Freville, P., and Goloub, P.: Comparison of the aerosol optical properties and size distribution retrieved by sun photometer with in situ measurements at midlatitude, Atmos. Meas. Tech., 9, 4569-4585, https://doi.org/10.5194/amt-9-4569-2016, 2016.

Clain, G., Baray, J.-L., Delmas, R., Keckhut, P., and Cammas, J.P.: A lagrangian approach to analyse the tropospheric ozone climatology in the tropics: Climatology of Stratosphere - Troposphere exchange at Reunion Island, Atmos. Environ., 44, 968975, 2010.

Colette, A., Aas, W., Banin, L., Braban, C. F., Ferm, M., Ortiz, A. G., Ilyn, I., Mar, K., Pandolfi, M., Putaud, J. P., Shatalov, V., Solberg, S., Spindler, G., Tarasova, O., Vana, M., Adani, M., Almodovar, P., Berton, E., Bessagnet, B., Bohlin-Nizzetto, P., Boruvkova, J., Breivik, K., Briganti, G., Cappelletti, A., Cuvelier, K., Derwent, R., D'Isidoro, M., Fagerli, H., Funk, C., Vivanco, M. G., Gonzalez Ortiz, A., Haeuber, R., Hueglin, C., Jenkins, S., Kerr, J., de Leeuw, F., Lynch, J., Manders, A., Mircea, M., Pay, M. T., Pritula, D., Querol, X., Raffort, V., Reiss, I., Roustan, Y., Sauvage, S., Scavo, K., Simpson, D., Smith, R., Tang, Y. S., Theobald, M., Torseth, K., Tsyro, S., Pul, A., Vidic, S., Wallasch, M., and Wind, P.: Air pollution trends in the EMEP region between 1990 and 2012, Joint Report of the EMEP Task Force on Measurements and Modelling (TFMM), NILU, EMEP/CCC-Report 1/2016, available at: https: //www.nilu.no/wp-content/uploads/dnn/cccr1-2016.pdf (last access: 10 June 2020), 2016.

Collaud Coen, M., Andrews, E., Aliaga, D., Andrade, M., Angelov, H., Bukowiecki, N., Ealo, M., Fialho, P., Flentje, H., Hallar, A. G., Hooda, R., Kalapov, I., Krejci, R., Lin, N.-H., Marinoni, A., Ming, J., Nguyen, N. A., Pandolfi, M., Pont, V., Ries, L., Rodríguez, S., Schauer, G., Sellegri, K., Sharma, S., Sun, J., Tunved, P., Velasquez, P., and Ruffieux, D.: Identification of topographic features influencing aerosol observations at high altitude stations, Atmos. Chem. Phys., 18, 12289-12313, https://doi.org/10.5194/acp-18-12289-2018, 2018.

Collaud Coen, M., Andrews, E., Alastuey, A., Arsov, T. P., Backman, J., Brem, B. T., Bukowiecki, N., Couret, C., Eleftheriadis, K., Flentje, H., Fiebig, M., Gysel-Beer, M., Hand, J. L., Hoffer, A., Hooda, R., Hueglin, C., Joubert, W., Keywood, M., Kim, J. E., Kim, S.-W., Labuschagne, C., Lin, N.-H., Lin, Y., Lund Myhre, C., Luoma, K., Lyamani, H., Marinoni, A., MayolBracero, O. L., Mihalopoulos, N., Pandolfi, M., Prats, N., Prenni, A. J., Putaud, J.-P., Ries, L., Reisen, F., Sellegri, K., Sharma, S., Sheridan, P., Sherman, J. P., Sun, J., Titos, G., Torres, E., Tuch, T., Weller, R., Wiedensohler, A., Zieger, P., and Laj, P.: Multi- decadal trend analysis of aerosol radiative properties at a global scale, Atmos. Chem. Phys. Discuss., https://doi.org/10.5194/acp2019-1174, in review, 2020.

COPERNICUS: Record-breaking temperatures for June, available at: https://climate.copernicus.eu/ record-breaking-temperatures-june, last access: 10 June 2020a.

COPERNICUS: Surface temperature, available at: https://climate. copernicus.eu/surface-temperature, last access: 10 June $2020 \mathrm{~b}$.

Crenn, V., Sciare, J., Croteau, P. L., Verlhac, S., Fröhlich, R., Belis, C. A., Aas, W., Äijälä, M., Alastuey, A., Artiñano, B., Baisnée, D., Bonnaire, N., Bressi, M., Canagaratna, M., Canonaco, F., Carbone, C., Cavalli, F., Coz, E., Cubison, M. J., Esser-Gietl, J. K., Green, D. C., Gros, V., Heikkinen, L., Herrmann, H., Lunder, C., Minguillón, M. C., Močnik, G., O’Dowd, C. D., Ovadnevaite, J., Petit, J.-E., Petralia, E., Poulain, L., Priestman, M., Riffault, V., Ripoll, A., Sarda-Estève, R., Slowik, J. G., Setyan, A., Wiedensohler, A., Baltensperger, U., Prévôt, A. S. H., Jayne, J. T., and Favez, O.: ACTRIS ACSM intercomparison - Part 1: Reproducibility of concentration and fragment results from 13 individual Quadrupole Aerosol Chemical Speciation Monitors (Q-ACSM) and consistency with co-located instruments, Atmos. Meas. Tech., 8, 5063-5087, https://doi.org/10.5194/amt-8-50632015, 2015.

Dall'Osto, M., Beddows, D. C. S., Asmi, A., Poulain, L., Hao, L., Freney, E., Allan, J. D., Canagaratna, M., Crippa, M., Bianchi, F., de Leeuw, G., Eriksson, A., Swietlicki, E., Hansson, H. C., Henzing, J. S., Granier, C., Zemankova, K., Laj, P., Onasch, T., Prevot, A., Putaud, J. P., Sellegri, K., Vidal, M., Virtanen, A., Simo, R., Worsnop, D., O’Dowd, C., Kulmala, M., and Harrison, R. M.: Novel insights on new particle formation derived from a pan-european observing system, Sci. Rep., 8, 1482, https://doi.org/10.1038/s41598-017-17343-9, 2018.

Deguillaume, L., Leriche, M., Desboeufs, K., Mailhot, G., George, C., and Chaumerliac, N.: Transition Metals in Atmospheric Liquid Phases: Sources, Reactivity, and Sensitive Parameters, Chem. Rev., 105, 3388-3431, https://doi.org/10.1021/cr040649c, 2005.

Deguillaume, L., Charbouillot, T., Joly, M., Vaïtilingom, M., Parazols, M., Marinoni, A., Amato, P., Delort, A.-M., Vinatier, V., Flossmann, A., Chaumerliac, N., Pichon, J. M., Houdier, S., Laj, P., Sellegri, K., Colomb, A., Brigante, M., and Mailhot, G.: Classification of clouds sampled at the puy de Dôme (France) based on $10 \mathrm{yr}$ of monitoring of their physicochemical properties, Atmos. Chem. Phys., 14, 1485-1506, https://doi.org/10.5194/acp14-1485-2014, 2014.

Dominutti, P., Keita, S., Bahino, J., Colomb, A., Liousse, C., Yoboué, V., Galy-Lacaux, C., Morris, E., Bouvier, L., Sauvage, S., and Borbon, A.: Anthropogenic VOCs in Abidjan, southern West Africa: from source quantification to atmospheric impacts, Atmos. Chem. Phys., 19, 11721-11741, https://doi.org/10.5194/acp-19-11721-2019, 2019.

Dubovik, O. and King, M. D.: A flexible inversion algorithm for retrieval of aerosol optical properties from Sun and sky radiance measurements, J. Geophys. Res.-Atmos., 105, 20673-20696, https://doi.org/10.1029/2000JD900282, 2000.

Duplissy, J., Gysel, M., Sjogren, S., Meyer, N., Good, N., Kammermann, L., Michaud, V., Weigel, R., Martins dos Santos, S., Gruening, C., Villani, P., Laj, P., Sellegri, K., Metzger, A., McFiggans, G. B., Wehrle, G., Richter, R., Dommen, J., Ris- 
tovski, Z., Baltensperger, U., and Weingartner, E.: Intercomparison study of six HTDMAs: results and recommendations, Atmos. Meas. Tech., 2, 363-378, https://doi.org/10.5194/amt-2363-2009, 2009.

EARLINET: https://earlinet.org/, last access: 10 June 2020.

EUMETNET: E-Profile web page, available at: http://eumetnet.eu/ activities/observations-programme/current-activities/e-profile/ radar-wind-profilers/, last access: 10 June 2020.

Farah, A., Freney, E., Chauvigné, A., Baray, J.-L., Rose, C., Picard, D., Colomb, A., Hadad, D., Abboud, M., Farah, W., and Sellegri, K.: Seasonal Variation of Aerosol Size Distribution Data at the Puy de Dôme Station with Emphasis on the Boundary Layer/Free Troposphere Segregation, Atmosphere, 9, 244, https://doi.org/10.3390/atmos9070244, 2018.

Farah, A., Freney, E., Canonaco, F., Prévot, A. S. H, Abboud, M., Farah, W., and Sellegri, K.: One year of on-line chemistry measurements of the non-refractory submicron aerosol at the Puyde-Dôme with an emphasis on organic aerosol sources, air mass transport and free troposphere/boundary layer conditions, Earth and Space Science, submitted, 2020.

Freney, E., Sellegri, K., Asmi, E., Rose, C., Chauvigne, A., Baray, J.-L., Colomb, A., Hervo, M., Montoux, N., Bouvier, L., and Picard, D.: Experimental Evidence of the Feeding of the Free Troposphere with Aerosol Particles from the Mixing Layer, Aerosol. Air Qual. Res., 16, 702-716, https://doi.org/10.4209/aaqr.2015.03.0164, 2016.

Freney, E., Zhang, Y., Croteau, P., Amodeo, T., Williams, L.,Truong, F., Petit, J.-E., Sciare, J., Sarda-Estève, R., Bonnaire, N., Crenn, V., Arumae, T., Aurela, M., Bougiatioti, K., Coz, E., Elste, T., Heikkinen, L., Minguillon, M.-C., Poulain, L., Riestman, M., Stavroulas, I., Tobler, A., Vasilescu, J., Zanca, N., Alastuey, A., Artinano, B., Carbone, C., Flentje, H., Green, D., Herrmann, H., Maasikmets, M., Marmureanu, L., Prévôt, A. S. H., Wiedensohler, A., Canagaratna, M., Gros, V., Jayne, J. T., and Favez, O.: The second ACTRIS inter-comparison (2016) for Aerosol Chemical Speciation Monitors (ACSM): Calibration protocols and in- strument performance evaluations, Aerosol. Sci. Technol., 53, 830-842, 2019.

Freney, E. J., Sellegri, K., Canonaco, F., Boulon, J., Hervo, M., Weigel, R., Pichon, J. M., Colomb, A., Prévôt, A. S. H., and Laj, P.: Seasonal variations in aerosol particle composition at the puy-de-Dôme research station in France, Atmos. Chem. Phys., 11, 13047-13059, https://doi.org/10.5194/acp-11-130472011, 2011.

Fréville, P., Montoux, N., Baray, J.-L., Chauvigné, A., Réveret, F., Hervo, M., Dionisi, D., Payen, G., and Sellegri, K.: LIDAR Developments at Clermont-Ferrand-France for Atmospheric Observation, Sensors, 15, 3041-3069, https://doi.org/10.3390/s150203041, 2015.

Fröhlich, R., Cubison, M. J., Slowik, J. G., Bukowiecki, N., Prévôt, A. S. H., Baltensperger, U., Schneider, J., Kimmel, J. R., Gonin, M., Rohner, U., Worsnop, D. R., and Jayne, J. T.: The ToF-ACSM: a portable aerosol chemical speciation monitor with TOFMS detection, Atmos. Meas. Tech., 6, 3225-3241, https://doi.org/10.5194/amt-6-3225-2013, 2013.

Gagné, S., Lehtipalo, K., Manninen, H. E., Nieminen, T., Schobesberger, S., Franchin, A., Yli-Juuti, T., Boulon, J., Sonntag, A., Mirme, S., Mirme, A., Hõrrak, U., Petäjä, T., Asmi, E., and Kulmala, M.: Intercomparison of air ion spectrometers: an evaluation of results in varying conditions, Atmos. Meas. Tech., 4, 805-822, https://doi.org/10.5194/amt-4-805-2011, 2011.

Gerber, H.: Liquid Water Content of Fogs and Hazes from Visible Light Scattering, J. Clim. Appl. Meteorol., 23, 1247-1252, https://doi.org/10.1175/15200450(1984)023<1247:LWCOFA >2.0.CO;2, 1984.

Gerber, H.: Direct measurement of suspended particulate volume concentration and far-infrared extinction coefficient with a laser-diffraction instrument, Appl. Optics, 30, 4824-4831, https://doi.org/10.1364/AO.30.004824, 1991.

Giannitrapani, M., Bowman, A., Scott, E., and Smith, R.: Sulphurdioxide in Europe: Statistical relationships between emissions and measured concentrations, Atmos. Environ., 40, 2524-2532, 2006.

Gilge, S., Plass-Duelmer, C., Fricke, W., Kaiser, A., Ries, L., Buchmann, B., and Steinbacher, M.: Ozone, carbon monoxide and nitrogen oxides time series at four alpine GAW mountain stations in central Europe, Atmos. Chem. Phys., 10, 12295-12316, https://doi.org/10.5194/acp-10-12295-2010, 2010.

Guyot, G., Gourbeyre, C., Febvre, G., Shcherbakov, V., Burnet, F., Dupont, J.-C., Sellegri, K., and Jourdan, O.: Quantitative evaluation of seven optical sensors for cloud microphysical measurements at the Puy-de-Dôme Observatory, France, Atmos. Meas. Tech., 8, 4347-4367, https://doi.org/10.5194/amt-8-4347-2015, 2015.

Hadad, D., Baray, J.-L., Montoux, N., Van Baelen, J., Fréville, P., Pichon, J.-M., Bosser, P., Ramonet, M., Yver Kwok, C., Bègue, N., and Duflot, V.: Surface and Tropospheric Water Vapor Variability and Decadal Trends at Two Supersites of CO-PDD (Cézeaux and Puy de Dôme) in Central France, Atmosphere, 9, 302, https://doi.org/10.3390/atmos9080302, 2018.

Hagen, M., van Baelen, J., and Richard, E.: Influence of the wind profile on the initiation of convection in mountainous terrain, Q. J. Roy. Meteor. Soc., 137, 224-235, https://doi.org/10.1002/qj.784, 2011.

Hervo, M., Sellegri, K., Pichon, J. M., Roger, J. C., and Laj, P.: Long term measurements of optical properties and their hygroscopic enhancement, Atmos. Chem. Phys. Discuss., 14, 27731-27767, https://doi.org/10.5194/acpd-14-27731-2014, 2014.

Hoerger, C. C., Claude, A., Plass-Duelmer, C., Reimann, S., Eckart, E., Steinbrecher, R., Aalto, J., Arduini, J., Bonnaire, N., Cape, J. N., Colomb, A., Connolly, R., Diskova, J., Dumitrean, P., Ehlers, C., Gros, V., Hakola, H., Hill, M., Hopkins, J. R., Jäger, J., Junek, R., Kajos, M. K., Klemp, D., Leuchner, M., Lewis, A. C., Locoge, N., Maione, M., Martin, D., Michl, K., Nemitz, E., O’Doherty, S., Pérez Ballesta, P., Ruuskanen, T. M., Sauvage, S., Schmidbauer, N., Spain, T. G., Straube, E., Vana, M., Vollmer, M. K., Wegener, R., and Wenger, A.: ACTRIS non-methane hydrocarbon intercomparison experiment in Europe to support WMO GAW and EMEP observation networks, Atmos. Meas. Tech., 8, 2715-2736, https://doi.org/10.5194/amt-8-2715-2015, 2015.

Holben, B. N., Eck, T. F., Slutsker, I., Tanré, D., Buis, J. P., Setzer, A., Vermote, E., Reagan, J. A., Kaufman, Y. J., Nakajima, T., Lavenu, F., Jankowiak, I., and Smirnov, A.: AERONET-A Federated Instrument Network and Data Archive for Aerosol Characterization, Remote Sens. Environ., 66, 1-16, https://doi.org/10.1016/S0034-4257(98)00031-5, 1998.

Holmgren, H., Sellegri, K., Hervo, M., Rose, C., Freney, E., Villani, P., and Laj, P.: Hygroscopic properties and mixing state 
of aerosol measured at the high-altitude site Puy de Dôme (1465 m a.s.1.), France, Atmos. Chem. Phys., 14, 9537-9554, https://doi.org/10.5194/acp-14-9537-2014, 2014.

ICOS: ICOS data portal, available at: https://data.icos-cp.eu/, last access: 10 June 2020.

IGN: GNSS database, available at: http://rgp.ign.fr, last access: 10 June 2020.

IPCC: Climate Change 2013: The Physical Science Basis. Contribution of Working Group I to the Fifth Assessment Report of the Intergovernmental Panel on Climate Change, Cambridge University Press, Cambridge, UK and New York, NY, USA, 2013.

IRSN: OPERA database, available at: https://www. mesure-radioactivite.fr/en\#/expert, last access: 10 June 2020.

Joly, M., Attard, E., Sancelme, M., Deguillaume, L., Guilbaud, C., Morris, C. E., Amato, P., and Delort, A.-M.: Ice nucleation activity of bacteria isolated from cloud water, Atmos. Environ., 70, 392-400, https://doi.org/10.1016/j.atmosenv.2013.01.027, 2013.

Joly, M., Amato, P., Deguillaume, L., Monier, M., Hoose, C., and Delort, A.-M.: Quantification of ice nuclei active at near $0{ }^{\circ} \mathrm{C}$ temperatures in low-altitude clouds at the Puy de Dôme atmospheric station, Atmos. Chem. Phys., 14, 8185-8195, https://doi.org/10.5194/acp-14-8185-2014, 2014.

Joly, M., Amato, P., Sancelme, M., Vinatier, V., Abrantes, M., Deguillaume, L., and Delort, A.-M.: Survival of microbial isolates from clouds toward simulated atmospheric stress factors, Atmos. Environ., 117, 92-98, https://doi.org/10.1016/j.atmosenv.2015.07.009, 2015.

Jonson, J. E., Simpson, D., Fagerli, H., and Solberg, S.: Can we explain the trends in European ozone levels?, Atmos. Chem. Phys., 6, 51-66, https://doi.org/10.5194/acp-6-51-2006, 2006.

Kangasluoma, J., Junninen, H., Lehtipalo, K., Mikkilä, J., Vanhanen, J., Attoui, M., Sipilä, M., Worsnop, D., Kulmala, M., and Petäjä, T.: Remarks on ion generation for CPC detection efficiency studies in sub-3-nm size range, Aerosol. Sci. Technol., 47, 556-563, https://doi.org/10.1080/02786826.2013.773393, 2013.

Kontkanen, J., Lehtipalo, K., Ahonen, L., Kangasluoma, J., Manninen, H. E., Hakala, J., Rose, C., Sellegri, K., Xiao, S., Wang, L., Qi, X., Nie, W., Ding, A., Yu, H., Lee, S., Kerminen, V.M., Petäjä, T., and Kulmala, M.: Measurements of sub-3 nm particles using a particle size magnifier in different environments: from clean mountain top to polluted megacities, Atmos. Chem. Phys., 17, 2163-2187, https://doi.org/10.5194/acp17-2163-2017, 2017.

Labbouz, L., Van Baelen, J., Tridon, F., Reverdy, M., Hagen, M., Bender, M., Dick, G., Schellander-Gorgas, T., and Planche, C.: Precipitation on the lee side of the Vosges Mountains: Multi-instrumental study of one case from the COPS campaign, Meteorol. Z., 22, 413-432, https://doi.org/10.1127/09412948/2013/0413, 2013.

Labbouz, L., Van Baelen, J., and Duroure, C.: Investigation of the links between water vapor field evolution and rain rate based on 5 years of measurements at a midlatitude site, Geophys. Res. Lett., 42, 9538-9545, https://doi.org/10.1002/2015GL066048, 2015.

Laj, P., Flossmann, A. I., Wobrock, W., Fuzzi, S., Orsi, G., Ricci, L., Mertes, S., Schwarzenböck, A., Heintzenberg, J., and Ten Brink, H.: Behaviour of $\mathrm{H}_{2} \mathrm{O}_{2}, \mathrm{NH}_{3}$, and black carbon in mixed-phase clouds during CIME, Atmos. Res., 58, 315-336, https://doi.org/10.1016/S0169-8095(01)00097-7, 2001.
Laj, P., Bigi, A., Rose, C., Andrews, E., Lund Myhre, C., Collaud Coen, M., Wiedensohler, A., Schultz, M., Ogren, J. A., Fiebig, M., Gliß, J., Mortier, A., Pandolfi, M., Petäjä, T., Kim, S.-W., Aas, W., Putaud, J.-P., Mayol-Bracero, O., Keywood, M., Labrador, L., Aalto, P., Ahlberg, E., Alados Arboledas, L., Alastuey, A., Andrade, M., Artíñano, B., Ausmeel, S., Arsov, T., Asmi, E., Backman, J., Baltensperger, U., Bastian, S., Bath, O., Beukes, J. P., Brem, B. T., Bukowiecki, N., Conil, S., Couret, C., Day, D., Dayantolis, W., Degorska, A., Dos Santos, S. M., Eleftheriadis, K., Fetfatzis, P., Favez, O., Flentje, H., Gini, M. I., Gregorič, A., Gysel-Beer, M., Hallar, G. A., Hand, J., Hoffer, A., Hueglin, C., Hooda, R. K., Hyvärinen, A., Kalapov, I., Kalivitis, N., Kasper-Giebl, A., Kim, J. E., Kouvarakis, G., Kranjc, I., Krejci, R., Kulmala, M., Labuschagne, C., Lee, H.-J., Lihavainen, H., Lin, N.-H., Löschau, G., Luoma, K., Marinoni, A., Meinhardt, F., Merkel, M., Metzger, J.-M., Mihalopoulos, N., Nguyen, N. A., Ondracek, J., Peréz, N., Perrone, M. R., Petit, J.-E., Picard, D., Pichon, J.-M., Pont, V., Prats, N., Prenni, A., Reisen, F., Romano, S., Sellegri, K., Sharma, S., Schauer, G., Sheridan, P., Sherman, J. P., Schütze, M., Schwerin, A., Sohmer, R., Sorribas, M., Steinbacher, M., Sun, J., Titos, G., Tokzko, B., Tuch, T., Tulet, P., Tunved, P., Vakkari, V., Velarde, F., Velasquez, P., Villani, P., Vratolis, S., Wang, S.-H., Weinhold, K., Weller, R., Yela, M., Yus-Diez, J., Zdimal, V., Zieger, P., and Zikova, N.: A global analysis of climate-relevant aerosol properties retrieved from the network of GAW near-surface observatories, Atmos. Meas. Tech. Discuss., https://doi.org/10.5194/amt-2019-499, in review, 2020.

Lallement, A., Vinatier, V., Brigante, M., Deguillaume, L., Delort, A. M., and Mailhot, G.: First evaluation of the effect of microorganisms on steady state hydroxyl radical concentrations in atmospheric waters, Chemosphere, 212, 715-722, https://doi.org/10.1016/j.chemosphere.2018.08.128, 2018a.

Lallement, A., Besaury, L., Tixier, E., Sancelme, M., Amato, P., Vinatier, V., Canet, I., Polyakova, O. V., Artaev, V. B., Lebedev, A. T., Deguillaume, L., Mailhot, G., and Delort, A.-M.: Potential for phenol biodegradation in cloud waters, Biogeosciences, 15, 5733-5744, https://doi.org/10.5194/bg-15-5733-2018, 2018b.

Lebedev, A. T., Polyakova, O. V., Mazur, D. M., Artaev, V. B., Canet, I., Lallement, A., Vaïtilingom, M., Deguillaume, L., and Delort, A.-M.: Detection of semi-volatile compounds in cloud waters by GCxGC-TOF-MS. Evidence of phenols and phthalates as priority pollutants, Environ. Pollut., 241, 616-625, https://doi.org/10.1016/j.envpol.2018.05.089, 2018.

Li, Q., Sritharathikhun, P., and Motomizu, S.: Development of Novel Reagent for Hantzsch Reaction for the Determination of Formaldehyde by Spectrophotometry and Fluorometry, Analytical sciences: the international journal of the Japan Society for Analytical Chemistry, 23, 413-417, https://doi.org/10.2116/analsci.23.413, 2007.

Lopez, M., Schmidt, M., Ramonet, M., Bonne, J.-L., Colomb, A., Kazan, V., Laj, P., and Pichon, J.-M.: Three years of semicontinuous greenhouse gas measurements at the Puy de Dôme station (central France), Atmos. Meas. Tech., 8, 3941-3958, https://doi.org/10.5194/amt-8-3941-2015, 2015.

Lothon, M., Barnéoud, P., Gabella, O., Lohou, F., Derrien, S., Rondi, S., Chiriaco, M., Bastin, S., Dupont, J.-C., Haeffelin, M., Badosa, J., Pascal, N., and Montoux, N.: ELIFAN, an algorithm for the estimation of cloud cover from sky imagers, At- 
mos. Meas. Tech., 12, 5519-5534, https://doi.org/10.5194/amt12-5519-2019, 2019.

Manninen, H. E., Nieminen, T., Asmi, E., Gagné, S., Häkkinen, S., Lehtipalo, K., Aalto, P., Vana, M., Mirme, A., Mirme, S., Hõrrak, U., Plass-Dülmer, C., Stange, G., Kiss, G., Hoffer, A., Törő, N., Moerman, M., Henzing, B., de Leeuw, G., Brinkenberg, M., Kouvarakis, G. N., Bougiatioti, A., Mihalopoulos, N., O’Dowd, C., Ceburnis, D., Arneth, A., Svenningsson, B., Swietlicki, E., Tarozzi, L., Decesari, S., Facchini, M. C., Birmili, W., Sonntag, A., Wiedensohler, A., Boulon, J., Sellegri, K., Laj, P., Gysel, M., Bukowiecki, N., Weingartner, E., Wehrle, G., Laaksonen, A., Hamed, A., Joutsensaari, J., Petäjä, T., Kerminen, V.-M., and Kulmala, M.: EUCAARI ion spectrometer measurements at 12 European sites - analysis of new particle formation events, Atmos. Chem. Phys., 10, 7907-7927, https://doi.org/10.5194/acp10-7907-2010, 2010.

Manninen, H. E., Mirme, S., Mirme, A., Petäjä, T., and Kulmala, M.: How to reliably detect molecular clusters and nucleation mode particles with Neutral cluster and Air Ion Spectrometer (NAIS), Atmos. Meas. Tech., 9, 3577-3605, https://doi.org/10.5194/amt-9-3577-2016, 2016.

Marinoni, A., Laj, P., Sellegri, K., and Mailhot, G.: Cloud chemistry at the Puy de Dôme: variability and relationships with environmental factors, Atmos. Chem. Phys., 4, 715-728, https://doi.org/10.5194/acp-4-715-2004, 2004.

Marinoni, A., Parazols, M., Brigante, M., Deguillaume, L., Amato, P., Delort, A.-M., Laj, P., and Mailhot, G.: Hydrogen peroxide in natural cloud water: Sources and photoreactivity, Atmos. Res., 101, 256-263, https://doi.org/10.1016/j.atmosres.2011.02.013, 2011.

Masson, O., de Vismes Ott, A., Bourcier, L., Paulat, P., Ribeiro, M., Pichon, J.-M., Sellegri, K., and Gurriaran, R.: Change of radioactive cesium $\left({ }^{137} \mathrm{Cs}\right.$ and $\left.{ }^{134} \mathrm{Cs}\right)$ content in cloud water at an elevated site in France, before and after the Fukushima nuclear accident: Comparison with radioactivity in rainwater and in aerosol particles, Atmos. Res., 151, 45-51, https://doi.org/10.1016/j.atmosres.2014.03.031, 2015.

Masson, O., Bieringer, J., Brattich, E., Dalheimer, A., Estier, S., Penev, I., Ringer, W., Schlosser, C., Steinkopff, T., Steinmann, P., Tositti, L., Van Beek, P., and Vismes-Ott, A. de: Variation in airborne ${ }^{134} \mathrm{Cs},{ }^{137} \mathrm{Cs}$, particulate ${ }^{131} \mathrm{I}$ and ${ }^{7} \mathrm{Be}$ maximum activities at high-altitude European locations after the arrival of Fukushima-labeled air masses, J. Environ. Radioactiv., 162-163, 14-22, https://doi.org/10.1016/j.jenvrad.2016.05.004, 2016.

Mirme, A., Tamm, E., Mordas, G., Vana, M., Uin, J., Mirme, S., Bernotas, T., Laakso, L., Hirsikko, A., and Kulmala, M.: A widerange multi-channel Air Ion Spectrometer, Boreal Environ. Res., 12, 247-264, 2007.

Mirme, S. and Mirme, A.: The mathematical principles and design of the NAIS - a spectrometer for the measurement of cluster ion and nanometer aerosol size distributions, Atmos. Meas. Tech., 6, 1061-1071, https://doi.org/10.5194/amt-6-1061-2013, 2013.

Mouchel-Vallon, C., Deguillaume, L., Monod, A., Perroux, H., Rose, C., Ghigo, G., Long, Y., Leriche, M., Aumont, B., Patryl, L., Armand, P., and Chaumerliac, N.: CLEPS 1.0: A new protocol for cloud aqueous phase oxidation of VOC mechanisms, Geosci. Model Dev., 10, 1339-1362, https://doi.org/10.5194/gmd-10-1339-2017, 2017.
NASA/GSFC: AERONET website, available at: http://aeronet.gsfc. nasa.gov, last access: 10 June 2020.

NILU: EBAS database, available at: http://ebas.nilu.no, last access: 10 June 2020.

Ng, N. L., Herndon, S. C., Trimborn, A., Canagaratna, M. R., Croteau, P. L., Onasch, T. B., Sueper, D., Worsnop, D. R., Zhang, Q., Sun, Y. L., and Jayne, J. T.: An aerosol chemical speciation monitor (ACSM) for routine monitoring of the composition and mass concentrations of ambient aerosol, Aerosol. Sci. Technol., 45, 780-794, https://doi.org/10.1080/02786826.2011.560211, 2011.

OMP: PAES database, available at: http://paes.aero.obs-mip.fr, last access: 10 June 2020.

OPGC: Internet portal, available at: http://wwwobs. univ-bpclermont.fr/SO/mesures/direct.php, last access 10 June 2020a.

OPGC: Virtual observatory, available at: http://wwwobs. univ-bpclermont.fr/vobs/index.php, last access: 10 June 2020b.

Pandolfi, M., Alados-Arboledas, L., Alastuey, A., Andrade, M., Angelov, C., Artiñano, B., Backman, J., Baltensperger, U., Bonasoni, P., Bukowiecki, N., Collaud Coen, M., Conil, S., Coz, E., Crenn, V., Dudoitis, V., Ealo, M., Eleftheriadis, K., Favez, O., Fetfatzis, P., Fiebig, M., Flentje, H., Ginot, P., Gysel, M., Henzing, B., Hoffer, A., Holubova Smejkalova, A., Kalapov, I., Kalivitis, N., Kouvarakis, G., Kristensson, A., Kulmala, M., Lihavainen, H., Lunder, C., Luoma, K., Lyamani, H., Marinoni, A., Mihalopoulos, N., Moerman, M., Nicolas, J., O’Dowd, C., Petäjä, T., Petit, J.-E., Pichon, J. M., Prokopciuk, N., Putaud, J.P., Rodríguez, S., Sciare, J., Sellegri, K., Swietlicki, E., Titos, G., Tuch, T., Tunved, P., Ulevicius, V., Vaishya, A., Vana, M., Virkkula, A., Vratolis, S., Weingartner, E., Wiedensohler, A., and Laj, P.: A European aerosol phenomenology - 6: scattering properties of atmospheric aerosol particles from 28 ACTRIS sites, Atmos. Chem. Phys., 18, 7877-7911, https://doi.org/10.5194/acp18-7877-2018, 2018.

Passananti, M., Vinatier, V., Delort, A.-M., Mailhot, G., and Brigante, M.: Siderophores in Cloud Waters and Potential Impact on Atmospheric Chemistry: Photoreactivity of Iron Complexes under Sun-Simulated Conditions, Environ. Sci. Technol., 50, 9324 9332, https://doi.org/10.1021/acs.est.6b02338, 2016.

Petzold, A. and Schönlinner, M.: Multi-angle absorption photometry - a new method for the measurement of aerosol light absorption and atmospheric black carbon, J. Aerosol Sci., 35, 421-441, https://doi.org/10.1016/j.jaerosci.2003.09.005, 2004.

Picard, D.: libszdist, HAL, available at https://hal. archives-ouvertes.fr/hal-01883795, last access: 10 June 2020.

Planche, C., Wobrock, W., Flossmann, A., Tridon, F., Labbouz, L., and Van Baelen, J.: Small scale topography influence on the formation of three convective systems observed during COPS over the Vosges Mountains, Meteorol. Z., 22, 395-411, https://doi.org/10.1127/0941-2948/2013/0402, 2013.

Pouzet, G., Peghaire, E., Aguès, M., Baray, J.-L., Conen, F., and Amato, P.: Atmospheric Processing and Variability of Biological Ice Nucleating Particles in Precipitation at Opme, France, Atmosphere, 8, 229, https://doi.org/10.3390/atmos8110229, 2017.

Putaud, J.-P., Raes, F., Van Dingenen, R., Bruggemann, E., Facchini, M.-C., Decesari, S., Fuzzi, S., Gehrig, R., Huglind, C., Laj, P., Lorbeer, G., Maenhaut, W., Mihalopoulos, N., Muller, K., 
Querol, X., Rodriguez, S., Schneider, J., Spindler, G., ten Brink, H., Torseth, K., and Wiedensohler, A.: A European aerosol phenomenology - 2: chemical characteristics of particulate matter at kerbside, urban, rural and background sites in Europe, Atmos. Environ., 38, 2579-2595, 2004

Ramonet, M., Ciais, P., Aalto, T., Aulagnier, C., Chevallier, F., Cipriano, D., Conway, T., Haszpra, L., Kazan, V., Meinhardt, F., Paris, J.-D., Schmid, M., Simmonds, P., Xueref-Rémy, I., and Necki, J.: A recent build-up of atmospheric $\mathrm{CO}_{2}$ over Europe. Part 1: observed signals and possible explanations, Tellus B, 62, 1-13, https://doi.org/10.1111/j.1600-0889.2009.00442.x, 2010.

Ramonet, M., Ciais, P., Apadula, F., Bastos, A., Bergamaschi, P., Blanc, P. E., Brunner, D., di Torchiaro, L. C., Calzolari, F., Chen, H., Chen, H., Chmura, L., Colomb, A., Conil, S., Cristofanelli, P., Cuevas, E., Curcoll, R., Delmotte, M., di Sarra, A., Emmenegger, L., Forster, G., Frumau, A., Gerbig, C., Gheusi, F., Hammer, S., Haszpra, L., Hatakka, J., Hazan, L., Heliasz, M., Henne, S., Hensen, A., Hermansen, O., Keronen, P., Kivi, R., Komínková, K., Kubistin, D., Laurent, O., Laurila, T., Lavric, J. V., Lehner, I., Lehtinen, K. E. J., Leskinen, A., Leuenberger, M., Levin, I., Lindauer, M. Lopez, M., Myhre, C. L., Mammarella, I., Manca, G., Manning, A., Marek, M. V., Marklund, P., Martin, D., Meinhardt, F., Mihalopoulos, N., Mölder, M., Morgui, J. A., Necki, J., O’Doherty, S., O’Dowd, C., Ottosson, M., Philippon, C., Piacentino, S., Pichon, J. M., Plass-Duelmer, C., Resovsky, A., Rivier, L., Rodó, X., Sha, M. K., Scheeren, H. A., Sferlazzo, D., Spain, T. G., Stanley, K. M., Steinbacher, M., Trisolino, P., Vermeulen, A., Vítková, G., Weyrauch, D., Xueref-Remy, I., Yala, K., and Kwok, Y. C.: The fingerprint of the summer 2018 drought in Europe on ground-based atmospheric $\mathrm{CO}_{2}$ measurements, Philos. T. Roy. Soc., in press, https://doi.org/10.1098/rstb.2019.0513, 2020.

RENAG: http://renag.resif.fr, last access: 10 June 2020.

Renard, P., Canet, I., Sancelme, M., Wirgot, N., Deguillaume, L., and Delort, A.-M.: Screening of cloud microorganisms isolated at the Puy de Dôme (France) station for the production of biosurfactants, Atmos. Chem. Phys., 16, 12347-12358, https://doi.org/10.5194/acp-16-12347-2016, 2016.

Roberts, G. C. and Nenes, A.: A continuous-flow streamwise thermal-gradient $\mathrm{CCN}$ chamber for atmospheric measurements, Aerosol. Sci. Technol., 39, 206-221, https://doi.org/10.1080/027868290913988, 2005.

Rose, C., Boulon, J., Hervo, M., Holmgren, H., Asmi, E., Ramonet, M., Laj, P., and Sellegri, K.: Long-term observations of cluster ion concentration, sources and sinks in clear sky conditions at the high-altitude site of the Puy de Dôme, France, Atmos. Chem. Phys., 13, 11573-11594, https://doi.org/10.5194/acp-13-115732013, 2013.

Rose, C., Sellegri, K., Asmi, E., Hervo, M., Freney, E., Colomb, A., Junninen, H., Duplissy, J., Sipilä, M., Kontkanen, J., Lehtipalo, K., and Kulmala, M.: Major contribution of neutral clusters to new particle formation at the interface between the boundary layer and the free troposphere, Atmos. Chem. Phys., 15, 34133428, https://doi.org/10.5194/acp-15-3413-2015, 2015.

Rose, C., Chaumerliac, N., Deguillaume, L., Perroux, H., MouchelVallon, C., Leriche, M., Patryl, L., and Armand, P.: Modeling the partitioning of organic chemical species in cloud phases with CLEPS (1.1), Atmos. Chem. Phys., 18, 2225-2242, https://doi.org/10.5194/acp-18-2225-2018, 2018.
Seck, I. and Van Baelen, J.: Geostatistical Merging of a SinglePolarized X-Band Weather Radar and a Sparse Rain Gauge Network over an Urban Catchment, Atmosphere, 9, 496, https://doi.org/10.3390/atmos9120496, 2018.

Sellegri, K., Laj, P., Marinoni, A., Dupuy, R., Legrand, M., and Preunkert, S.: Contribution of gaseous and particulate species to droplet solute composition at the Puy de Dôme, France, Atmos. Chem. Phys., 3, 1509-1522, https://doi.org/10.5194/acp-3-15092003, 2003a.

Sellegri, K., Laj, P., Dupuy, R., Legrand, M., Preunkert, S., and Putaud, J.-P.: Size-dependent scavenging efficiencies of multicomponent atmospheric aerosols in clouds, J. Geophys. Res., 108, 4334, https://doi.org/10.1029/2002JD002749, 2003b.

Sellegri, K., Rose, C., Marinoni, A., Lupi, A., Wiedensohler, A., Andrade, M., Bonasoni, P., and Laj, P.: New Particle Formation: A Review of Ground-Based Observations at Mountain Research Stations, Atmosphere, 10, 493, https://doi.org/10.3390/atmos10090493, 2019.

Sjogren, S., Gysel, M., Weingartner, E., Alfarra, M. R., Duplissy, J., Cozic, J., Crosier, J., Coe, H., and Baltensperger, U.: Hygroscopicity of the submicrometer aerosol at the high-alpine site Jungfraujoch, $3580 \mathrm{~m}$ a.s.1., Switzerland, Atmos. Chem. Phys., 8, 5715-5729, https://doi.org/10.5194/acp-8-5715-2008, 2008.

Stookey, L. L.: Ferrozine-a new spectrophotometric reagent for iron, Anal. Chem., 42, 779-781, https://doi.org/10.1021/ac60289a016, 1970.

Sturm, P., Leuenberger, M., and Schmidt, M.: Atmospheric $\mathrm{O}_{2}$, $\mathrm{CO}_{2}$ and $\delta^{13} \mathrm{C}$ observations from the remote sites Jungfraujoch, Switzerland, and Puy de Dôme, France, Geophys. Res. Lett., 32, L17811, https://doi.org/10.1029/2005GL023304, 2005.

Svenningsson, B., Hansson, H.-C., Wiedensohler, A., Noone, K., Ogren, J., Hallberg, A., and Colvile, R.: Hygroscopic growth of aerosol particles and its influence on nucleation scavenging in cloud: Experimental results from Kleiner Feldberg, J. Atmos. Chem., 19, 129-152, https://doi.org/10.1007/BF00696586, 1994.

Svenningsson, B., Hansson, H.-C., Martinsson, B., Wiedensohler, A., Swietlicki, E., Cederfelt, S.-I., Wendisch, M., Bower, K. N., Choularton, T. W., and Colvile, R. N.: Cloud droplet nucleation scavenging in relation to the size and hygroscopic behaviour of aerosol particles, Atmos. Environ., 31, 2463-2475, https://doi.org/10.1016/S1352-2310(96)00179-3, 1997.

Tridon, F., Van Baelen, J., and Pointin, Y.: Aliasing in Micro Rain Radar data due to strong vertical winds, Geophys. Res. Lett., 38, L02804, https://doi.org/10.1029/2010GL046018, 2011.

VAISALA: Vaisala HUMICAP Probes user's guide, available at: https://www.vaisala.com/sites/default/files/documents/ HMP45AD-User-Guide-U274EN.pdf, last access: 10 June 2020.

Vaitilingom, M., Charbouillot, T., Deguillaume, L., Maisonobe, R., Parazols, M., Amato, P., Sancelme, M., and Delort, A.-M.: Atmospheric chemistry of carboxylic acids: microbial implication versus photochemistry, Atmos. Chem. Phys., 11, 8721-8733, https://doi.org/10.5194/acp-11-8721-2011, 2011.

Vaïtilingom, M., Attard, E., Gaiani, N., Sancelme, M., Deguillaume, L., Flossmann, A. I., Amato, P., and Delort, A.-M.: Long-term features of cloud microbiology at the puy de Dôme (France), Atmos. Environ., 56, 88-100, https://doi.org/10.1016/j.atmosenv.2012.03.072, 2012. 
Vaïtilingom, M., Deguillaume, L., Vinatier, V., Sancelme, M., Amato, P., Chaumerliac, N., and Delort, A.-M.: Potential impact of microbial activity on the oxidant capacity and organic carbon budget in clouds, P. Natl. Acad. Sci. USA, 110, 559, https://doi.org/10.1073/pnas.1205743110, 2013.

Valentino, F. L., Leuenberger, M., Uglietti, C., and Sturm, P.: Measurements and trend analysis of $\mathrm{O}_{2}, \mathrm{CO}_{2}$ and $\delta^{13} \mathrm{C}$ of $\mathrm{CO}_{2}$ from the high altitude research station Junfgraujoch, Switzerland - A comparison with the observations from the remote site Puy de Dôme, France, Sci. Total Environ., 391, 203-210, https://doi.org/10.1016/j.scitotenv.2007.10.009, 2008.

Van Baelen, J. and Penide, G.: Study of water vapor vertical variability and possible cloud formation with a small network of GPS stations, Geophys. Res. Lett., 36, L02804, https://doi.org/10.1029/2008GL036148, 2009.

Van Baelen, J., Reverdy, M., Tridon, F., Labbouz, L., Dick, G., Bender, M., and Hagen, M.: On the relationship between water vapour field evolution and the life cycle of precipitation systems, Q. J. Roy. Meteor. Soc., 137, 204-223, https://doi.org/10.1002/qj.785, 2011.

Vanhanen, J., Mikkilä, J., Lehtipalo, K., Sipilä, M., Manninen, H. E., Siivola, E., Petäjä, T., and Kulmala, M.: Particle size magnifier for nano-CN detection, Aerosol. Sci. Technol., 45, 533-542, https://doi.org/10.1080/02786826.2010.547889, 2011.

Venzac, H., Sellegri, K., and Laj, P.: Nucleation events detected at the high altitude site of the Puy de Dôme Research Station, France, Boreal Environ. Res., 12, 345-359, 2007.

Venzac, H., Sellegri, K., Villani, P., Picard, D., and Laj, P.: Seasonal variation of aerosol size distributions in the free troposphere and residual layer at the puy de Dôme station, France, Atmos. Chem. Phys., 9, 1465-1478, https://doi.org/10.5194/acp-9-1465-2009, 2009.

Villani, P., Picard, D., Michaud, V., Laj, P., and Wiedensohler, A.: Design and validation of a Volatility Hygroscopic Tandem Differential Mobility Analyzer (VH-TDMA) to characterize the relationships between the thermal and hygroscopic properties of atmospheric aerosol particles, Aerosol. Sci. Technol., 42, 729741, https://doi.org/10.1080/02786820802255668, 2008.

Vinatier, V., Wirgot, N., Joly, M., Sancelme, M., Abrantes, M., Deguillaume, L., and Delort, A.-M.: Siderophores in Cloud Waters and Potential Impact on Atmospheric Chemistry: Production by Microorganisms Isolated at the Puy de Dôme Station, Environ. Sci. Technol., 50, 9315-9323, https://doi.org/10.1021/acs.est.6b02335, 2016.

Voisin, D., Legrand, M., and Chaumerliac, N.: Scavenging of acidic gases $\left(\mathrm{HCOOH}, \mathrm{CH}_{3} \mathrm{COOH}, \mathrm{HNO}_{3}, \mathrm{HCl}\right.$, and $\left.\mathrm{SO}_{2}\right)$ and ammonia in mixed liquid-solid water clouds at the Puy de Dôme mountain (France), J. Geophys. Res.-Atmos., 105, 6817-6835, https://doi.org/10.1029/1999JD900983, 2000.
Wang, M., Perroux, H., Fleuret, J., Bianco, A., Bouvier, L., Colomb, A., Borbon, A., and Deguillaume, L.: Anthropogenic and biogenic hydrophobic VOCs detected in clouds at the puy de Dôme station using Stir Bar Sorptive Extraction: Deviation from the Henry's law prediction, Atmos. Res., 237, 104844, https://doi.org/10.1016/j.atmosres.2020.104844, 2020.

Wiedensohler, A., Birmili, W., Nowak, A., Sonntag, A., Weinhold, K., Merkel, M., Wehner, B., Tuch, T., Pfeifer, S., Fiebig, M., Fjäraa, A. M., Asmi, E., Sellegri, K., Depuy, R., Venzac, H., Villani, P., Laj, P., Aalto, P., Ogren, J. A., Swietlicki, E., Williams, P., Roldin, P., Quincey, P., Hüglin, C., Fierz-Schmidhauser, R., Gysel, M., Weingartner, E., Riccobono, F., Santos, S., Grüning, C., Faloon, K., Beddows, D., Harrison, R., Monahan, C., Jennings, S. G., O’Dowd, C. D., Marinoni, A., Horn, H.-G., Keck, L., Jiang, J., Scheckman, J., McMurry, P. H., Deng, Z., Zhao, C. S., Moerman, M., Henzing, B., de Leeuw, G., Löschau, G., and Bastian, S.: Mobility particle size spectrometers: harmonization of technical standards and data structure to facilitate high quality long-term observations of atmospheric particle number size distributions, Atmos. Meas. Tech., 5, 657-685, https://doi.org/10.5194/amt-5-657-2012, 2012.

Wirgot, N., Vinatier, V., Deguillaume, L., Sancelme, M., and Delort, A.-M.: $\mathrm{H}_{2} \mathrm{O}_{2}$ modulates the energetic metabolism of the cloud microbiome, Atmos. Chem. Phys., 17, 14841-14851, https://doi.org/10.5194/acp-17-14841-2017, 2017.

Wulfmeyer, V., Behrendt, A., Kottmeier, C., Corsmeier, U., Barthlott, C., Craig, G. C., Hagen, M., Althausen, D., Aoshima, F., Arpagaus, M., Bauer, H.-S., Bennett, L., Blyth, A., Brandau, C., Champollion, C., Crewell, S., Dick, G., Di Girolamo, P., Dorninger, M., Dufournet, Y., Eigenmann, R., Engelmann, R., Flamant, C., Foken, T., Gorgas, T., Grzeschik, M., Handwerker, J., Hauck, C., Höller, H., Junkermann, W., Kalthoff, N., Kiemle, C., Klink, S., König, M., Krauss, L., Long, C. N., Madonna, F., Mobbs, S., Neininger, B., Pal, S., Peters, G., Pigeon, G., Richard, E., Rotach, M. W., Russchenberg, H., Schwitalla, T., Smith, V., Steinacker, R., Trentmann, J., Turner, D. D., van Baelen, J., Vogt, S., Volkert, H., Weckwerth, T., Wernli, H., Wieser, A., and Wirth, M.: The Convective and Orographically-induced Precipitation Study (COPS): the scientific strategy, the field phase, and research highlights, Q. J. Roy. Meteor. Soc., 137, 3-30, https://doi.org/10.1002/qj.752, 2011.

Zwiebel, J., Van Baelen, J., Anquetin, S., Pointin, Y., and Boudevillain, B.: Impacts of orography and rain intensity on rainfall structure. The case of the HyMeX IOP7a event, Q. J. Roy. Meteor. Soc., 142, 310-319, https://doi.org/10.1002/qj.2679, 2016. 